\title{
Phosphonium salts and P-ylides
}

\author{
Maurizio Selva,* Alvise Perosa and Marco Noè \\ DOI: 10.1039/9781782626930-00132
}

\section{Introduction}

The present review is aimed at describing the state-of-the-art, for the period January-December 2014, of two pillar classes of phosphoruscontaining compounds, the phosphonium salts and ylides. The importance of these derivatives is revealed by the very high number of references cited herein. For the Reader's convenience, topics are organized to offer an introductory survey on the methods of preparation and characterisation of both types of compounds, followed by an analysis of applicative and curiosity driven research. A special section is devoted to phosphonium-based ionic liquids (PILs).

\section{Phosphonium salts}

\subsection{Synthesis and characterisation}

The quaternisation of phosphines with electrophiles or Brønsted acids is doubtlessly the most typical and simple reaction for the preparation of phosphonium salts. The preparation of most phosphonium salts reported in the period surveyed by this review followed this approach. The structures of these compounds are summarised in Fig. 1.

Mechanistic studies on the quaternisation reaction were performed by Salin and co-workers. ${ }^{1}$ They investigated the strong acceleration of the quaternization of triphenylphosphine using maleic and cis-aconitic acids as electrophiles. The kinetic effect was rationalized on the basis of spatial structures of the generated zwitterions.

Rates and energy barriers of degenerate halide substitution on tetracoordinate halophosphonium cations were measured using NMR techniques (VT and EXSY) and computational methods by Gilheany and coworkers. ${ }^{2}$ Experiments were in favour of a two-step mechanism for the formation of a pentacoordinate dihalophosphorane via backside attack followed by dissociation. The reaction of phosphines with a highly electrophilic in situ generated aryne was reported to proceed with the formation of a phosphonium zwitterion by Biju and coworkers. ${ }^{3}$ The latter further reacted with water or aldehydes, yielding the corresponding aromatic phosphonium salt or benzaphosphole systems, respectively. The oxidation of highly hindered triarylphosphines with $\mathrm{O}_{2}$ in the presence of $\mathrm{AgClO}_{4}$ was studied by Sasaki and co-workers. ${ }^{4}$ A five membered ring phosphonium salt was observed as the product. Structural properties of phosphonium molecules were also investigated by NMR in a

Dipartimento di Scienze Molecolari e Nanosistemi, Università Ca' Foscari Venezia, Centre for Sustainable Technologies, Via Torino 155, 30172 Venezia Mestre, Italy. E-mail: selva@unive.it 


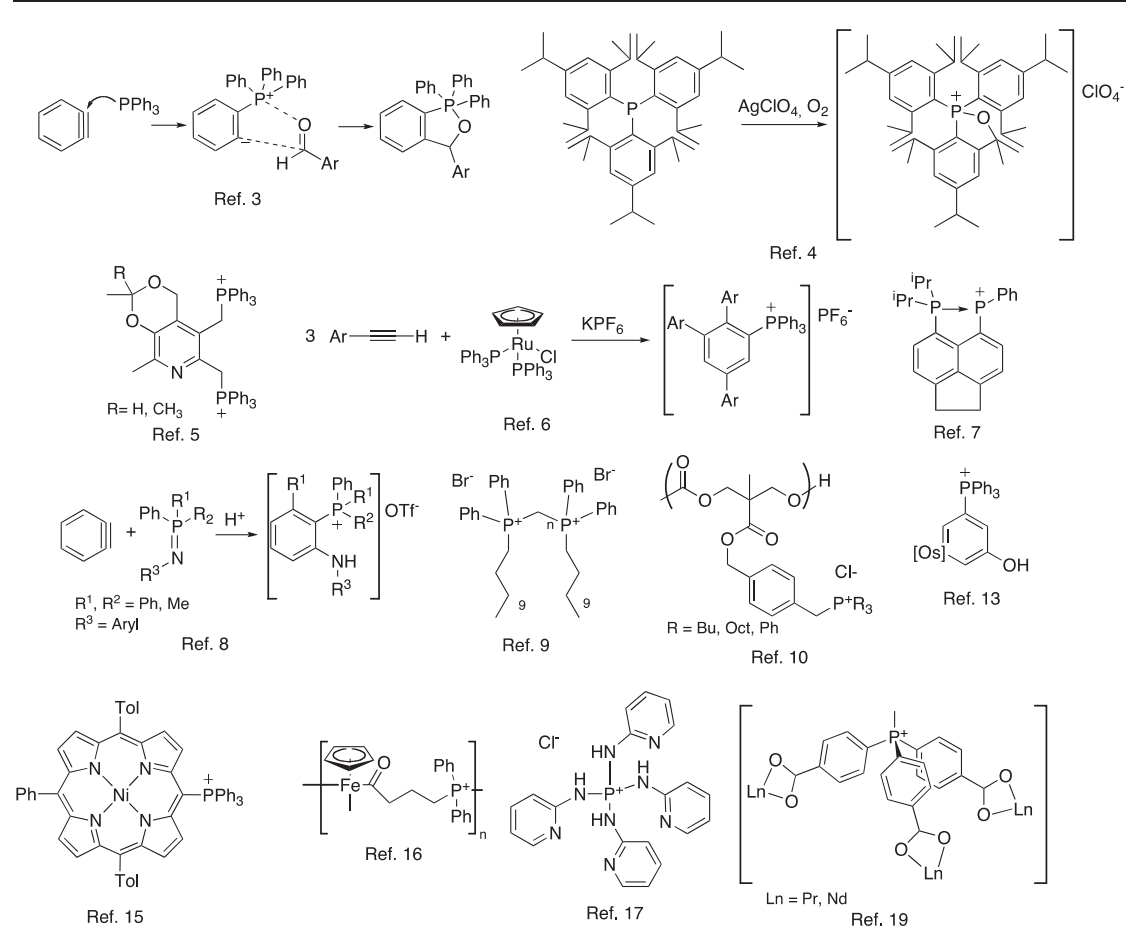

Fig. 1 Structures of phosphonium salts described throughout ref. 3-19.

paper by Aganova et al., who described two pyridoxine-substituted phosphonium salts. ${ }^{5}$ Lin and $\mathrm{Chen}^{6}$ reported that $\left(\eta^{5}-\mathrm{C}_{5} \mathrm{H}_{7}\right)\left(\mathrm{PPh}_{3}\right)_{2} \mathrm{RuCl}$ catalysed the dimerization of arylalkynes when used in amounts as low as $1 \mathrm{~mol} \%$. Surprisingly, stoichiometric amounts of the same ruthenium complex led to the formation of the cyclotrimerization product, yielding polyarylphosphonium salts. Kilian and co-workers reported the synthesis and reactivity of a peri-backbone-supported phosphonium-phosphine system $^{7}$ which showed a fascinating behaviour when combined with different molecular complexes. Analogously, Lopez-Leonardo et al. ${ }^{8}$ reported the $\pi$-insertion reactions of arynes into the $\mathrm{P}=\mathrm{N}$ bonds, which proceeded through zwitterions and led to the formation of 2-aminoarylphosphonium salts. In a study by Long and co-workers, bis(diphenylphosphino)alkanes were treated with excess 1-bromododecane to prepare gemini phosphonium surfactants. ${ }^{9}$ The properties of such compounds were investigated via isothermal titration calorimetry and solution rheology. Some of them were also electrospun to generate uniform fibers. Phosphonium-functionalised polymeric materials such as aliphatic polycarbonates containing pendant benzyl chloride groups were synthesized by Hedrick and co-workers via organocatalytic ring-opening polymerization. ${ }^{10}$ The latter were then functionalised with diethanolamine, phosphonium, and azide groups.

Phosphonium groups were also attached to a polypeptide. In particular, the synthesis, characterisation and cell-penetrating properties of a tributylphosphonium-tagged polymer were described by Cheng and coworkers. ${ }^{11}$ The preparation of a polysiloxane functionalised via a 
hydrosilylation reaction with allyltributylphosphonium bromide was reported by Liang et al. ${ }^{12}$ Such a polymer showed a very low glass transition temperature and high ion content.

Phosphonium moieties also found applications in the field of organometallic chemistry. Zhang, Xia and co-workers prepared and characterised an osmaphenol complex (in which osmium is part of the aromatic ring) bearing a triphenylphosphonium group. ${ }^{13}$ The use of phosphonium groups in the preparation of this class of organometallic compound is very common as observed in a recent review by Cao et $a l^{14}$ Dimé et al. reported that controlled potential electrolysis of a triarylmesosubstituted Ni(II) porphyrin in the presence of triphenylphosphine as a nucleophile allowed the electrochemical synthesis of the corresponding phosphonium derivative ${ }^{15}$ Polymeric organometallic materials were also described. Ragogna, Gilroy and co-workers reported the synthesis and characterization of a class of highly-metallised, redox-active polyelectrolytes having phosphonium groups as a scaffold for the installation of transition metals. ${ }^{16}$ Pyrolysis of thin films of these polyelectrolytes resulted in the production of magnetite crystallites and illdefined carbon-, phosphorus- and oxygen-rich phases in char. Pal, Jana and Nayek studied the use of tetrakis(2-pyridylamino)phosphonium chloride as ligand precursor. ${ }^{17}$ Both mononuclear complexes and a coordination polymer were obtained by using $\mathrm{Zn}, \mathrm{Ni}$, $\mathrm{Co}$ and $\mathrm{Cu}$. The oxidation product of the same ligand was used in the preparation of discrete and polymeric $\mathrm{Cu}$ (II) complexes by Boomishankar and co-workers. ${ }^{18}$ Wood, Humphrey and co-workers obtained two new isostructural materials by the reaction of $\mathrm{Pr}$ and $\mathrm{Nd}$ complexes with a tris( $p$-carboxylated) methyl-triphenylphosphonium ligand. ${ }^{19}$ The later allowed access to materials with uncommon metal-to-ligand ratios. A series of new mononuclear and heteronuclear complexes of carboxylate phosphonium betaines with biologically important metals (Zn(II), Cd(II), Hg(II) and $\mathrm{Cu}(\mathrm{II}))$ were obtained by Galkina et $a l^{20}{ }^{20}$ The ligand binding mode was clarified by X ray diffraction (XRD).

Phosphonium cations are often incorporated to obtain crystals suitable for XRD structural characterisation. This approach has been employed for studies on: (i) the reduction of rhenates(vII) with hydrogen chloride; ${ }^{21}$ (ii) the structure of bis(iso-maleonitriledithiolate)nickelate(II); ${ }^{22}$ and (iii) the structural comparison of phosphonium- and arsenic-dithiocarbamates. ${ }^{23}$ X-ray diffraction was also used in the characterization of tetra- $n$-butylphosphonium bromide semiclathrate hydrate. ${ }^{24}$

The latter class of compounds elicited a great interest because of their ability to entrap gas molecules, of which carbon dioxide is a remarkable example. Paricaud and co-workers reported an interesting insight on the dissociation conditions of $\mathrm{CO}_{2}$ from several ammonium salts and tetra- $n$-butyl phosphonium bromide $\left(\left[\mathrm{P}_{4444}\right] \mathrm{Br}\right)$ semiclathrate hydrates. ${ }^{25}$ Ye et $a ._{.}{ }^{26}$ described a comparison between phase equilibrium and morphology characteristics of hydrates formed by $\left[\mathrm{N}_{4444}\right] \mathrm{Cl}$ and $\left[\mathrm{P}_{4444}\right] \mathrm{Cl}$ with and without $\mathrm{CO}_{2}$.

Phosphonium salts are involved in the preparation and use of Frustrated Lewis Pairs (FLP). The Erker group studied the reaction of 
intermolecular FLPs such as $t-\mathrm{Bu}_{3} \mathrm{P} / \mathrm{B}\left(\mathrm{C}_{6} \mathrm{~F}_{5}\right)_{3}$ and $(o-\mathrm{Tolyl})_{3} \mathrm{P} / \mathrm{B}\left(\mathrm{C}_{6} \mathrm{~F}_{5}\right)_{3}$ with the conjugated enyne 2-methylbutenyne (Scheme 1). ${ }^{27}$

The same research group also described the first example of the phospha-Stork reaction. ${ }^{28}$ The carbon-carbon coupling of aryl aldehydes with bulky vinyl phosphanes (i.e. mesityldivinylphosphine) was possible with the help of $\left.\mathrm{B}_{(} \mathrm{C}_{6} \mathrm{~F}_{5}\right)_{3}$. In addition the reaction of dimesityl(vinyl)phosphine with bulky enones yielded the corresponding substituted cyclobutane products (Scheme 2).

The analogy of such compounds with iminium cations was manifest and it was underlined by further work of the group. ${ }^{29}$ Most recently, they also reported the phosphonium assisted preparation of heterocyclic five membered zwitterionic borata-diene compounds (Scheme 3). ${ }^{30}$

A new dicationic phosphonium salt, characterised by a high Lewis acidity, was described by Stephan and co-workers (Scheme 4). ${ }^{31}$ Studies on the reactivity of this compound showed its potential as Lewis acid catalyst for the hydro-defluorination of fluoroalkanes and the hydrosilylation of olefins.

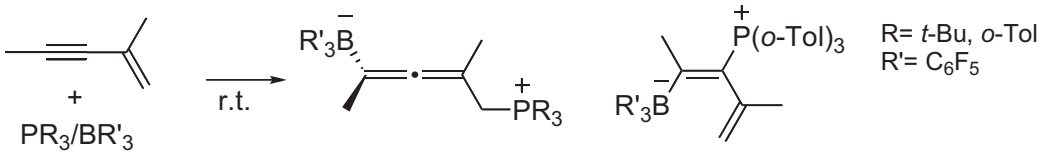

Scheme 1 Reaction of the phosphine/borane FLPs with 2-methylbutenyne.

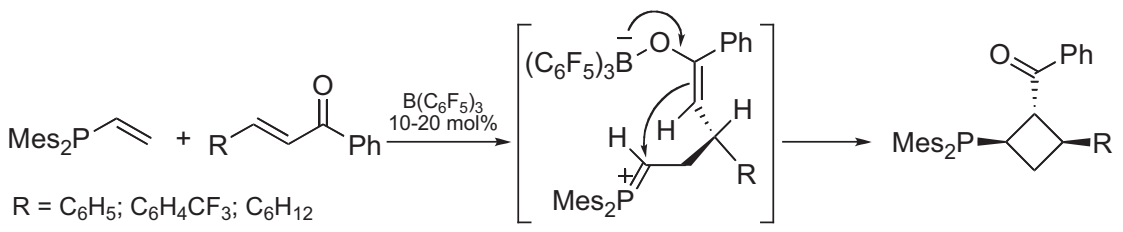

Scheme $2 \mathrm{~B}\left(\mathrm{C}_{6} \mathrm{~F}_{5}\right)_{3}$ assisted coupling of dimesityl(vinyl)phosphine with enones.

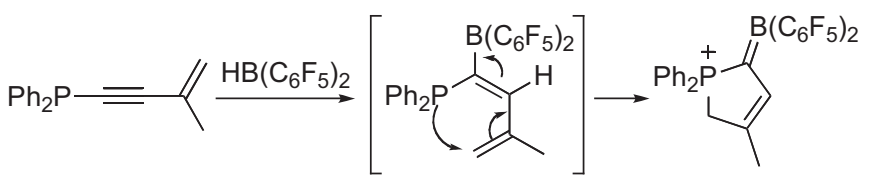

Scheme 3 Preparation of heterocyclic five membered zwitterionic borata-dienes.

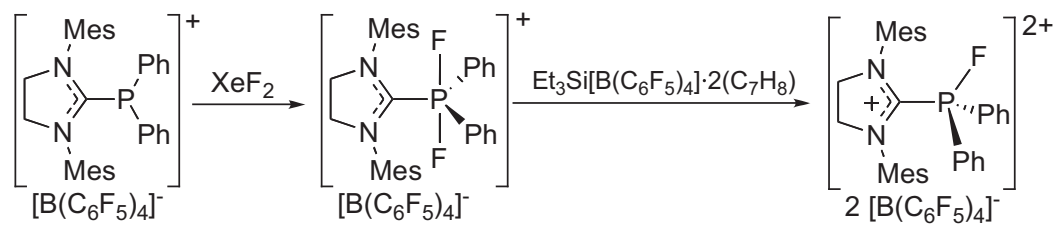

Scheme 4 Preparation of a dicationic phosphonium-imidazolium salt. 
Wang and co-workers synthesised a phosphine-borane Lewis pair connected by a U-shaped linker (Fig. 2). ${ }^{32}$ The photo-physical properties of this compound were examined and compared with the corresponding phosphonium salt, obtained by methylation with MeI, and the $\mathrm{Au}(\mathrm{I})$ and $\mathrm{Pt}(\mathrm{II})$ complexes where the phosphine-borane Lewis pair was used as a ligand.

In the field of supramolecular chemistry phosphonium salts frequently appear as host modifiers. For example, the self-assembling behaviour of a tetracationic phosphonium porphyrin with CdTe quantum dots was investigated by electrochemical methods. ${ }^{33}$ In a remarkable study by Ganguly, Das and co-workers, the use of two phosphonium moieties allowed the preparation of a compound bearing active methylene functionalities which preferably bind to $\mathrm{F}^{-}$and $\mathrm{OAc}^{-}$species. ${ }^{34}$ Phosphonium cations can also act as guest species. Wang et al. reported ${ }^{35,36}$ experimental and in silico investigations on the mechanism of ion recognition of calix[4]pyrrole bis-phosphonate receptors by ethylammonium and tetramethylphosphonium cations.

\subsection{Applications in synthesis}

The particular features of phosphonium salts were exploited for a number of synthetic applications in 2014. Phosphonium chloride salts found applications as chlorine source and as modifiers for homogeneous catalyst systems. As an example, Müller, Rosenthal and co-workers reported the study of a chromium-based catalyst for the selective trimerization of ethylene. ${ }^{37} \mathrm{~A}$ phosphonium precursor of the type ([cyclo$\left.\left.\left(\mathrm{PR}_{2} \mathrm{CH}_{2} \mathrm{CH}(\mathrm{OH})^{-}\right)_{2}\right][\mathrm{Br}]_{2}\right)$ was used for the preparation of iron(II) complexes containing unsymmetrical $\mathrm{P}-\mathrm{N}-\mathrm{P}^{\prime}$ pincer ligands (Scheme 5). The group of Prof. Morris tested these compounds as catalysts for the asymmetric hydrogenation of ketones and imines. ${ }^{38}$

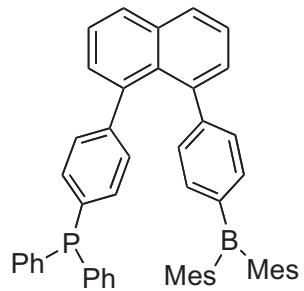

Fig. 2 U-shaped linker-connected phosphine-borane Lewis pair.

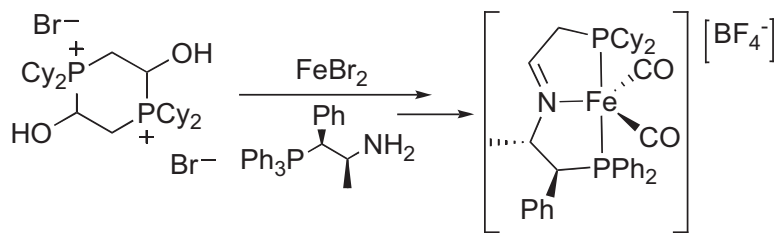

Scheme 5 [cyclo- $\left.\left(\mathrm{PR}_{2} \mathrm{CH}_{2} \mathrm{CH}(\mathrm{OH})^{-}\right)_{2}\right][\mathrm{Br}]_{2}$ as precursors for asymmetric organometallic catalysts. 
The $\left[{ }^{99} \mathrm{TcO}_{4}\right]^{-}$anion strongly interacts with quaternary phosphonium cations. This feature was exploited for the preparation of Tc complexes. Tridentate ligands such as 1,4,7-triazacyclononane (tacn) were used to replace $\left[\mathrm{R}_{4} \mathrm{P}-\mathrm{O}\right]^{-}$groups, thereby forming a water stable $\left[{ }^{99 \mathrm{~m}} \mathrm{Tc}^{\mathrm{VII}} \mathrm{O}_{3}(\text { tacn })\right]^{+}$complex, as reported by Alberto and co-workers. ${ }^{39}$ Methallyloxytris(dimethylamino)phosphonium hexafluorophosphate $\left[\mathrm{C}_{4} \mathrm{H}_{7} \mathrm{OP}\left(\mathrm{NMe}_{2}\right)_{3}\right] \mathrm{PF}_{6}{ }^{-}$was used by Dridi, Mechria and Msaddek as an allylating agent for the synthesis of cationic $\eta^{3}$-methallylpalladium complexes. $^{40}$ A very easy procedure for the preparation of 2-carboxyethyltriphenyl phosphonium tribromide, was reported by Dey and Dhar. ${ }^{41}$ The catalytic activity of this salt was found to be excellent for the silylation of alcohols and thiols by hexamethyl disilazane. Covalent anchoring of a triphenylphosphonium moiety on the surface of silica nanoparticles (NPs) was described by Hajipour and Azizi. ${ }^{42}$ These authors also reported the preparation of a palladium complex anchored to the phosphonium-modified silica NPs. The resulting material was tested as catalyst for the Heck reaction in water.

The features of the phosphonium functional group were exploited by Mukhopadhyay and co-workers in order to achieve isolation of the first naphthalenediimide (NDI) radical ion (Scheme 6). ${ }^{43}$

Reichl and Radosevich investigated the preparation of $Z$-enediynes by a vicinal dialkynylation of triaryl(aryl-ethynyl)phosphonium cations (Scheme 7). ${ }^{44}$ The reaction proceeded under mild transition metal-free conditions, with an excellent control of configuration.

The Cavicchi group reported the synthesis of tributyl- and triphenylphosphonium functionalised RAFT agents and their use in the bulk, thermally initiated polymerization of styrene (Fig. 3). ${ }^{45}$

Phosphonium salts can also appear as synthetic intermediates. An example was reported by Manna and co-workers. ${ }^{46}$ In the preparation of $1 \mathrm{H}$ indazoles from $o$-aminobenzoximes in the presence of triphenylphosphine,

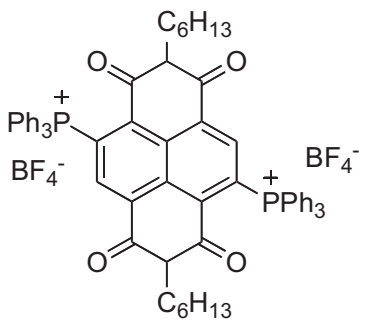

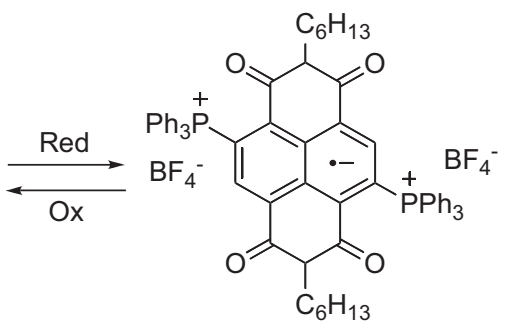

Scheme 6 First example of naphthalendiimide radical anion.<smiles></smiles><smiles>BrC#C[Tl]</smiles>

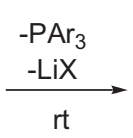<smiles>BrC#CC(Br)C(Br)C#CBr</smiles>

Scheme 7 Dialkynylation of triaryl(arylethynyl)phosphonium cations. 


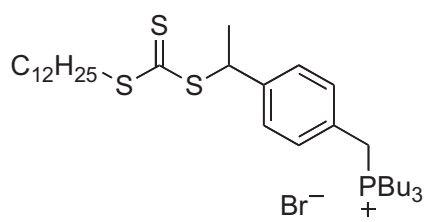

Fig. 3 Phosphonium-functionalised RAFT reagent.<smiles>C[I-][Pb]ON=C(c1ccccc1N)c1ccccc1N</smiles>

Scheme 8 Triphenylphosphonium assisted N-N bond formation.

$\mathrm{I}_{2}$, and imidazole, a phosphonium derivative is formed and acts as leaving group (Scheme 8).

In work by Ji et al., ${ }^{47}$ the reaction of $\alpha$-hydroxyallylphosphinates with $\mathrm{Ph}_{3} \mathrm{P}$ and $\mathrm{CCl}_{4}$ was investigated: the substitution of hydroxyl and migration of double bond allowed the preparation of $\gamma$-chloroallylphosphinates with a high stereoselectivity. These authors proposed a mechanism by which an in situ-formed phosphonium cation acted as a Lewis acid (Scheme 9).

The formation of a phosphonium moiety as protecting group was the key for the first ketone selective alkylation in the presence of reactive enones, as reported by Fujioka and co-workers. ${ }^{48}$ In the field of phase transfer catalysis (PTC), a review article by Remond and Juge described the use of P-chirogenic organophosphorus compounds in asymmetric organocatalysed processes. ${ }^{49}$ Shirakawa et al. reported the use of chiral bifunctional quaternary phosphonium bromide catalysts in the nucleophilic aromatic substitution reaction of 3-aryloxindoles (Scheme 10). ${ }^{50}$ The presence of a urea moiety in the chiral phase transfer catalyst was crucial to induce high enantioselectivity.

Kadyrov and Hackenberger investigated the use of a series of ammonium and phosphonium catalysts in the biphasic oxidative cleavage of long chain olefins with aqueous hydrogen peroxide catalyzed by $\mathrm{Na}_{2} \mathrm{WO}_{4} /$ $\mathrm{H}_{3} \mathrm{PO}_{4} / \mathrm{PTC}^{51}$

Among coupling agents, (benzotriazol-1-yloxy)tris(dimethylamino)phosphonium hexafluorophosphate (BOP) is an important representative in the field of peptide coupling. In a paper by Kumar et al., an efficient and straightforward pathway for the synthesis of 2-arylated quinoline derivatives proceeded via the one-pot cross-coupling of boronic acids and 2-OH quinoline derivatives. The latter was activated in situ by BOP. ${ }^{52}$ Lakshman and co-workers also described a reaction of BOP with alcohols in the presence of a base. The resulting 1-alkoxy-1H-benzo- and 7-azabenzotriazoles were isolated and characterised..$^{53}$ Saito and Wada compared the use of BOP with other different phosphonium-based coupling agents for solid-phase peptide synthesis. ${ }^{54}$ These authors demonstrated that 3-nitro-1,2,4-triazol-1-yl-tris(pyrrolidin-1-yl)phosphonium hexafluorophosphate (Fig. 4) gave the best results. 


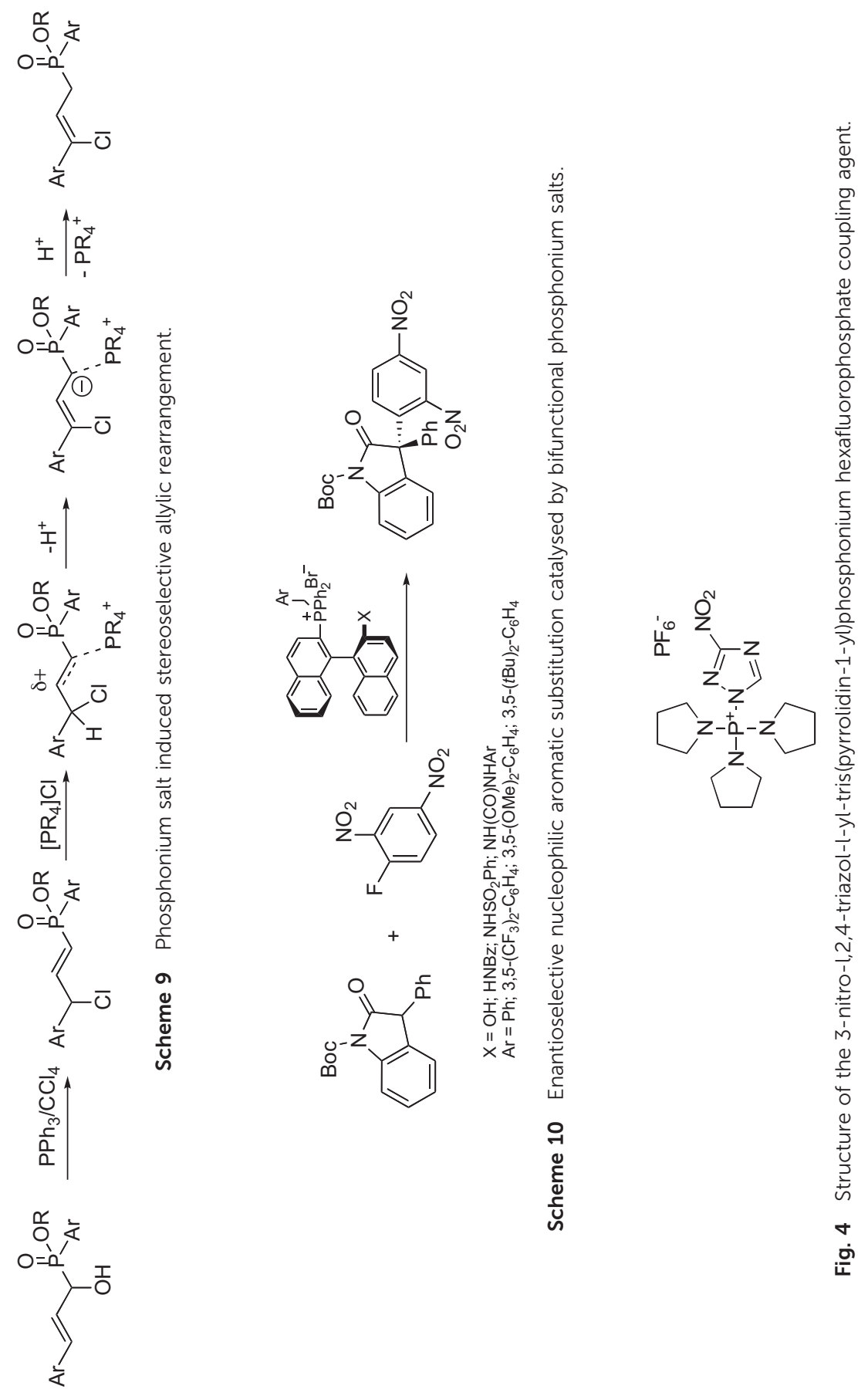




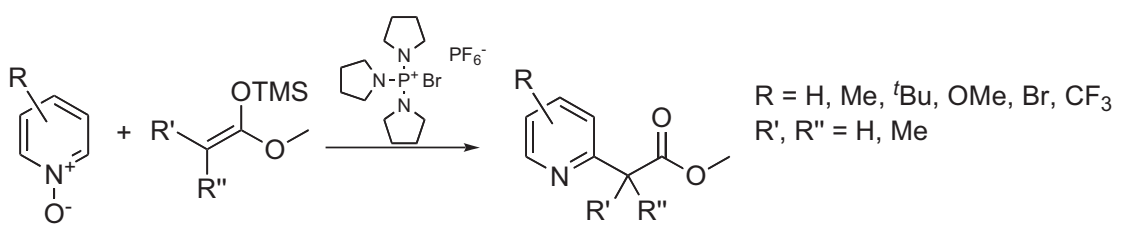

Scheme 11 PyBroP promoted addition of silyl ketene acetals to azine-N-oxides.

A similar reagent, bromotripyrrolidinophosphonium hexafluorophosphate (PyBroP) (Scheme 11) was investigated for the addition of silylketene acetals to azine- $\mathrm{N}$-oxides. This procedure afforded several $\alpha-(2-$ azaheteroaryl)acetates. ${ }^{55}$

Tetrakis-(hydroxymethylene)phosphonium salts $\left(\left[\mathrm{P}\left(\mathrm{CH}_{2} \mathrm{OH}\right)_{4}\right]^{+}\right.$or THP) have found significant applications in recent years. THP salts exchanged with different anions were widely reported for the production of gels. ${ }^{56-60}$ The chloride salt (THPC) was used as micro- and nano-particle stabiliser, ${ }^{61-63}$ and in the preparation of a new leather flame retardant. ${ }^{64}$ The sulphate salt (THPS) was successfully employed as a metabolic uncoupler to reduce sludge production. ${ }^{65} \mathrm{Gu}$ and $\mathrm{Li}$ also investigated the application of THPS in the mitigation of Desulfovibrio vulgaris biofilm and bio-corrosion pitting. ${ }^{66}$ Finally, THPS was reported as a reagent: it was transformed to the multifunctional monomer tris(allyloxymethyl)phosphine oxide for the preparation of two kinds of new phosphorus-containing crosslinked polymer materials. ${ }^{67,68}$

\subsection{Medical and biological applications}

In medicinal chemistry, the ability of phosphonium salts to accumulate in mitochondria was exploited for different purposes. Antonenko and coworkers prepared a triphenylphosphonium-functionalised fluorescein as a probe that accumulates in mitochondria. ${ }^{69}$ The compound proved to facilitate proton transfer across membranes and mitochondrial respiration. A mitochondria-targeted, phosphonium-tagged Ebselen drug was synthesised and tested by Stoyanovsky, Kagan and Bayir. ${ }^{70}$ The modified metabolism of peroxides caused by the drug was speculated to mitigate the effect of ionising radiation exposure.

As previously mentioned, phosphonium salts may activate $\left[\mathrm{TcO}_{4}\right]^{-}$. This feature was used to obtain ${ }^{99} \mathrm{Tc}$ complexes for imaging in radiomedicine ${ }^{71,72}$ Similarly, phosphonium salts were used as agents for PET imaging based on labelled ${ }^{18} \mathrm{~F}$ compounds. ${ }^{73-82}$ A structure-activity relationship study of a library of novel bifunctional Gd(III) complexes covalently bonded to arylphosphonium cations was reported by Morrison et al. ${ }^{83}$ Such complexes were designed for potential application in binary cancer therapies such as neutron capture and photon activation therapies. Mononuclear $\mathrm{Cu}$ (II) complexes of hydrazone ligands containing a triphenylphosphonium moiety were synthesized and characterized by Tan and co workers. ${ }^{84}$ One of the prepared complexes showed a remarkable high cytotoxicity against a human prostate adenocarcinoma cell line (PC-3). Cook and co-workers demonstrated that the 
incorporation of the alkyltriphenylphosphonium function significantly increased the concentration and biological activity of a series of phenothiazine derivatives. ${ }^{85}$ The most active compound showed inhibition of $M$. tuberculosis growth at $0.5 \mu \mathrm{g} \mathrm{mL} \mathrm{L}^{-1}$. In a paper by Odinokov and coworkers, the functionalization of betulin and betulinic acid with triphenylphosphonium groups was described.$^{86}$ The in vitro tests demonstrated a high antischistosomal activity of triphenylphosphonium derivatives of triterpenoids against newly transformed schistosomula and adult worms of Schistosoma mansoni. $N$-succinimidyloxycarbonylmethyl)tris(2,4,6-trimethoxyphenyl)phosphonium bromide (TMPP) was efficiently used as a labelling agent for protein $\mathrm{N}$ termini derivatisation. This approach allowed the reduction of annotation errors in the translational start codon. ${ }^{87}$ Turfus and co-workers reported the use of phosphonium groups for signal enhancement of glucuronide conjugates in LC-MS/MS for forensic purposes. ${ }^{88}$ A number of drug glucuronides were successfully derivatized with 3-[tris(trimethoxyphenyl)phosphonium]-1-propanamine to introduce cationic functionality. The antimicrobial properties of phosphonium compounds was extensively described and used for many applications. A novel antibacterial ethyltriphenylphosphonium bromidepolyacrylonitrile fiber was obtained by Zhao and co-workers through cation exchange starting from the sodium form of the resin. ${ }^{89,90}$ The results showed good antibacterial abilities against E. coli and S. aureus. Guo et al. detailed the preparation of $N$-phosphonium chitosans (NPCSs) with different loadings $(3 \%, 13 \%$ and $21 \%)$. These compounds were evaluated as polymeric antibacterial agents ${ }^{91}$ Ao and co-workers described the preparation of novel polymeric triphenyl- and tributylquaternary phosphonium salt bactericides. ${ }^{92}$ Structural characterizations and thermostability tests showed that all the bactericides had excellent thermal stabilities, especially in the case of triphenylphosphonium derivatives. Xiao and co-workers developed a novel quaternary phosphonium-type cationic polyacrylamide with pendant butyltriphenylphosphonium bromide acting as a bactericidal moiety. ${ }^{93}$ Atomic force microscopy (AFM) was employed to track the dynamic process of killing bacteria and to investigate the antibacterial mechanism. The results indicated that the incorporation of quaternary phosphonium salt imparted both antibacterial and antiviral activity to the material. In a study by $\mathrm{Li}$ et $a l^{94}{ }^{94}$ rubber was firstly ring-opened by bromoacetic acid and then modified by antimicrobial quaternary phosphonium groups. A novel insoluble bactericidal ceramisite filler was obtained and characterised by Zhang, Lü and Han. ${ }^{95}$ The material was obtained by immobilizing 3-(trimethoxysilyl)-1-propanamine onto the surface of ceramisite and then, by further reacting the amine function with (bromopropyl)triphenylphosphonium bromide. A paper by Kong et al. described the use of 4-carboxybutyltriphenylphosphonium bromide to obtain a grafted cellulose. ${ }^{96}$ The product showed good antibacterial property against E. coli. Phosphonium groups with antimicrobial activity were also grafted onto carbon nano-tubes (Karamanos, Kallitsis and co-workers) ${ }^{97}$ and activated carbon spheres (Shi and co-workers). ${ }^{98}$ 


\subsection{Miscellaneous applications}

Rey, Corma and co-workers described the preparation of a new microporous zeolite silicoborate with interconnected small and medium pores. ${ }^{99}$ This interesting new material was obtained using the 1,4butanediylbis-[tris(dimethylamino)]phosphonium dication as an organic structure director agent. The most common crystalline phases of polyvinylfluoride are $\alpha$ and $\beta$. The latter is desired because of its piezo- and pyroelectric properties. Tiwari, Misra and Khakhar investigated the ability of benzyltriphenylphosphonium chloride to directly nucleate the $\beta$ phase from melt. ${ }^{100}$ Different triphenylphosphonium halide salts were investigated as corrosion inhibitors for mild steel in phosphoric ${ }^{101,102}$ and sulphuric acid. ${ }^{103}$ Butyltriphenyl phosphonium salts were tested for limiting the corrosion of the zinc negative electrode of zinc-cerium hybrid redox flow batteries in methanesulfonic acid. ${ }^{104}$ The reaction between tetrahydroxymethylphosphonium sulfate and different fatty acids allowed Aiad and co-workers to produce the corresponding surfactants exhibiting corrosion protection ability and biocidal effects. ${ }^{105}$

In a review article on the preparation of ion-exchange materials and membranes, phosphonium groups were claimed to be rarely used, mainly due to their relatively low chemical stability. ${ }^{106}$ In this field, however, several recent applications of phosphonium salts were reported. In a paper by Chevalier and co-workers, the preparation of elastomeric polymethylsiloxane membranes bearing cationic exchanging sites, was achieved via quaternisation reactions between an alkylbromide functionalised material and triphenylphosphine. ${ }^{107}$ Wang et al. reported the remarkable features of a tris(2,4,6-trimethoxyphenyl) phosphonium chloride-substituted polyethersulfone membrane. ${ }^{108}$ This material exhibited a water permeability 35 times higher than the unsubstituted analogue. The hydroxide form of the same membrane was developed by Yan and co-workers. ${ }^{109}$ Such a material showed the best performance for $\mathrm{CO}_{2}$ separation when compared to imidazolium and ammonium analogues. He and co-workers produced a quaternary phosphoniumfunctionalized poly(ether ether ketone) which proved to be a highly conductive and alkali-stable hydroxide exchange membrane, suitable for fuel cell applications. ${ }^{110}$ Other polymers were reported by the Balsara group that developed a series of poly[(styrene)-block-((2-acryloxy)ethyltributylphosphoniumbromide)] diblock copolymers. ${ }^{111}$ These materials showed a low water uptake and high anionic conductivity due to the hydrophobic character of the tributylphosphonium cations.

Long and co-workers described the synthesis of poly(ethylene glycol)based, cationic polyurethanes with pendant phosphonium groups in the hard segment. ${ }^{112}$

Negrea et al. reported the preparation of a polymer composed of phosphonium pendant groups impregnated with crown ether (dibenzo18-crown-6). This material was loaded with iron ions to investigate arsenic removal from aqueous solutions. ${ }^{113}$

Phosphonium cations can also intercalate in clays. Different studies were reported on the interaction of different phosphonium cations with bentonites ${ }^{114,115}$ and montmorillonites. ${ }^{116}$ The use of 
phosphonium-modified clays for the preparation of polymer-organoclay nanocomposites was also extensively studied. For example, hydrophobic phosphonium salts bearing long alkyl chains or aromatic substituents were used to enhance the affinity of clays for polypropylene, ${ }^{117}$ polycarbonate ${ }^{118,119}$ and EPDM synthetic rubber. ${ }^{120}$ Wang et al. reported the preparation of a series of dendrimer-based montmorillonites and modified organic clay minerals, by using tetrahydroxymethylphosphonium chloride as starting material. ${ }^{121}$ The swelling and exfoliation behaviour of protonated layered oxides using tetra- $n$-butylphosphonium hydroxide $\left[\mathrm{P}_{4444}\right][\mathrm{OH}]$, was examined by Sasaki and co-workers. ${ }^{122}$ Quaternary ammonium cationic polymers, such as poly-(diallyldimethylammonium chloride) are widely used for drinking water purification, but they are suspected to produce carcinogenic $N$-nitrosamines during chloramine-based disinfection. For this reason, Mitch and co-workers synthesised and tested the phosphonium cationic polymer analogue. ${ }^{123}$ Plugs caused by natural gas hydrates are a costly problem, and their prevention is a major concern for the oil and gas industry. Magnusson and Kelland evaluated the synergism of five tetraalkylphosphonium bromide salts with $N$-vinylcaprolactam-based polymers as kinetic hydrate inhibitors and antiagglomerants. ${ }^{124}$ The stability of aqueous $\left[\mathrm{P}_{4444}\right][\mathrm{OH}]$ solutions and their potential for wheat straw extraction were investigated by Hyväkkö et al. ${ }^{125}$

\section{Phosphonium-based ionic liquids (PILs)}

Phosphonium-based ionic liquids (PILs) have elicited a phenomenal interest due to their low viscosity and high thermal and electrochemical stability, especially when compared with ammonium analogues. To evaluate possible applications of PILs, several studies investigated the physico-chemical properties of such compounds, while, at the same time, computational methods were developed to predict the viscosities, densities, etc. of PILs.

The focus of the following paragraph is mostly on PILs, but also considered are phosphonium-based deep eutectic solvents (PDES).

\subsection{Preparation and characterisation}

In recent years the chemistry related to the preparation of ILs has received valuable contributions. A review article by Jangu and Long highlighted remarkable applications of phosphonium- and imidazolium-based ionic liquids for the preparation of polyelectrolytes. ${ }^{126}$ Heinicke and co-workers described the preparation of zwitterionic phosphonioglycolates obtained by reaction of phosphines with glyoxylic acid hydrate (Fig. 5). ${ }^{127}$ The thermal stability of the zwitterionic compounds was investigated. Lall-Ramnarine et al. reported on the synthesis and characterization of four new cyclic phosphonium bis(trifluoromethylsulfonyl)amide ILs with aliphatic and aromatic pendant groups (Fig. 5). ${ }^{128}$ These compounds proved slightly less conductive than their cyclic ammonium congeners. Warner and co-workers described a new class of PILs obtained from anionic fluorescein derivatives paired to 
phosphonium cations ${ }^{129}$ These PILs were fluorescent probes for highly selective and sensitive detection of albumins. The synthesis and detailed characterization of tetraalkyl phosphonium oxalate ionic liquids were described by Quiroz-Guzman et al. ${ }^{130}$ Metal-containing PILs can also be prepared. A review by Estager, Holbrey and Swadzba-Kwasny focused on the preparation, properties and application of halometallate ILs. ${ }^{131}$ In this field, Strauch and co-workers discussed the crystallographic and EPR spectroscopic characterisation of five tetrachlorocuprate(II) complexes, explicitly bis(benzyltriethylammonium)-, bis(trimethylphenylammonium)-, bis(ethyltriphenylphosphonium)-, bis(benzyl-triphenylphosphonium)-, and bis(tetraphenylarsonium)tetrachloridocuprate(II). ${ }^{132}$

In work by Santos and co-workers, the preparation and characterisation of four magnetic ionic liquids based on the trihexyl(tetradecyl)phosphonium cation and different magnetic anions, namely $\left(\left[\mathrm{P}_{66614}\right]_{2}\left[\mathrm{CoCl}_{4}\right],\left[\mathrm{P}_{66614}\right]\left[\mathrm{FeCl}_{4}\right],\left[\mathrm{P}_{66614}\right]_{2}\left[\mathrm{MnCl}_{4}\right]\right.$ and $\left.\left[\mathrm{P}_{66614}\right]_{3}\left[\mathrm{GdCl}_{6}\right]\right)$, were reported. ${ }^{133}$ Also reported were density, viscosity and thermal properties, together with magnetic susceptibility, and carbon dioxide solubility. Kübler and Sundermeyer reported the synthesis and characterisation of new unsymmetrically-substituted ferrocenyl-phosphonium ionic liquids (Fig. 5) ${ }^{134}$ Functionalisation of the cyclopentadienyl ring was accomplished through a Friedel-Crafts phosphorylation. Wu and co-workers developed the synthesis of ammonium and phosphonium polyoxometallate ionic liquids. ${ }^{135}$ The latter compounds had a layered type structure and exhibited a phase transformation below $100^{\circ} \mathrm{C}$.

The effects of pressure and temperature on the physico-chemical properties of PILs were also examined. ${ }^{136,137}$ Different theoretical predictive models were developed on the subject. ${ }^{138,139}$ Noteworthy were theoretical investigations on the cation-anion interactions in PILs compared to ammonium ionic liquids, ${ }^{140}$ and an all-atomistic force field for a new class of halogen-free chelated orthoborate PILs. ${ }^{141}$ A study was also reported on an ion contribution equation of state based on electrolyte perturbation theory for the calculation of ILs densities. ${ }^{142}$

Photoinduced intramolecular charge transfer dynamics of 4-(9anthryl)- $N, N$-dimethylaniline and 9,9'-bianthryl, was investigated by Nagasawa, Miyasaka and co-workers via time-resolved fluorescence spectroscopy in several ILs. ${ }^{143}$ It was shown that the dynamic Stokes shift in the sub-ns to ns time range was solute-dependent in PILs. This behaviour was discussed from the viewpoint of the hierarchy of the solvation dynamics. The molecular and electronic structures of six PILs,

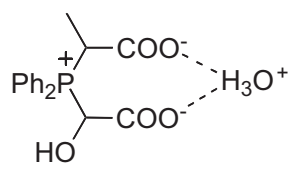

Ref. 127

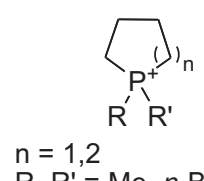

$\mathrm{R}, \mathrm{R}^{\prime}=\mathrm{Me}, n-\mathrm{Bu}, \mathrm{Ph}$

Ref. 128

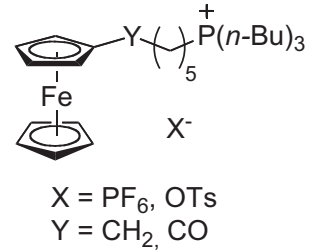

Ref. 134

Fig. 5 Structures of PILs described throughout ref. 127-134. 
all bearing the $\left[\mathrm{P}_{66614}\right]$ cation, were obtained via DFT quantum chemical calculations by Clara Wren and co-workers. ${ }^{144} \mathrm{~A}$ strong correlations between the calculated and the measured physical and chemical properties was observed. Yonekura and Grinstaff prepared a series of mono- and di-cationic phosphonium cations and combined them with seven monoanionic counterions. ${ }^{145}$ The effect of anion size and chemical structure on the rheological and conductive properties of the resultant ILs was studied. Blundell and Licence investigated the properties of a series of ammonium-based ionic liquids and their phosphonium analogues using X-ray Photoelectron Spectroscopy (XPS). ${ }^{146}$ The analysis revealed that only for short alkyl chains anion, the N-P substitution had a significant impact on the electronic environment of the anion. The same subject was investigated by Carvalho et al. through the measurement of densities, viscosities, melting temperatures, activity coefficients at infinite dilution, refractive indices, and toxicity against Vibrio fischeri. ${ }^{147}$ New insights on the ionic liquid-vacuum outer atomic surface were studied by Villar Garcia et al. ${ }^{148}$ Elements present in the surface of 23 ionic liquids were identified using high sensitivity low-energy ion scattering.

The radiation stability of a variety of imidazolium, quaternary ammonium, and phosphonium cation-based ILs was investigated by LaVerne and co-workers. ${ }^{149} \gamma$-Rays, $2-15 \mathrm{MeV}$ protons and 5-20 MeV helium ions were used to examine the potential hazards for application of ILs in advanced nuclear fuel cycles. Santos et al. evaluated the toxicity of ILs to microorganisms of interest in the food industry, in order to assess their suitability as solvents in biotechnological processes such as food production via microbial synthesis. ${ }^{150}$ Forsyth and co-workers employed anisotropic MRI contrast to investigate the structure of organic ionic plastic crystals. ${ }^{151}$ This approach made available a new characterization method for understanding polycrystalline domain structure and transport in plastic crystals and other solid-state conductors. For example, triethyl(methyl)phosphonium bis(fluorosulfonyl)imide samples with different thermal history demonstrated vast variations in microcrystallite alignment. Another exciting new technique was reported by Lago and coworkers. ${ }^{152}$ The Z-scan technique was used to characterise the nonlinear refraction induced by a train of ultrashort laser pulses for a set of ionic liquids. This was related to structural parameters such as cation and anion type, and alkyl chain length in the cation. Among other parameters, viscosity of pure ILs, ${ }^{153}$ as well as of their mixtures with molecular solvents, ${ }^{154}$ was of interest. Also, ternary systems consisting of an IL, an organic solvent and water were considered. ${ }^{155}$ The interaction of ILs with common solvents as well as with other ILs was carefully investigated. Heitz and co-workers reported a study on $\left[\mathrm{P}_{66614}\right][\mathrm{Cl}] /$ methanol binary systems. A non-linear dependence of viscosity on mole fraction was observed below $X_{\mathrm{IL}}<0.1$ while the data vary linearly with mole fraction for $X_{\mathrm{IL}}>0.1{ }^{156}$ Studies on mutual miscibility of tetrafluoroborate PILs with common solvents, such as cyclic hydrocarbons ${ }^{157}$ and diols ${ }^{158}$ were also reported. Mixtures of immiscible ionic liquids including PILs were investigated by Palomar and co-workers, ${ }^{159}$ 
demonstrating the potential of biphasic IL mixtures for extraction/ separation procedures. The Coutinho group observed that mixtures of ionic liquids enabled the formation of eutectic systems with very low melting points. ${ }^{160}$ The solubility of sodium chloride in phosphoniumbased deep eutectic solvents was studied by Mjalli and co-workers. ${ }^{161}$ Many investigations were focussed on the use of ionic liquids for carbon dioxide sorption and fixation technologies. ${ }^{162-165}$ and PDES. ${ }^{166}$ Taskspecific PILS based on the $\left[\mathrm{P}_{66614}\right]$ cation and aprotic heterocyclic anions were specifically designed for $\mathrm{CO}_{2}$ capture by the Brennecke group. ${ }^{167}$ Amino acid-based anions were used for the preparation of PILs for carbon dioxide manipulation. Trihexyltetradecylphosphonium lysinate demonstrated a very promising activity for the reversible absorption of $\mathrm{CO}_{2} \cdot{ }^{168}$ Similarly, glycinate salts bearing $\left[\mathrm{P}_{66614}\right],\left[\mathrm{P}_{4444}\right]$ and $\left[\mathrm{P}_{2225}\right]$ cations were prepared and tested as carriers of $\mathrm{CO}_{2}$ through membranes. ${ }^{169}$ The $\mathrm{CO}_{2} / \mathrm{N}_{2}$ permselectivity was improved using triethyl (pentyl)phosphonium glycinate. The solubility of other gases such as methane, ethane, ethylene and propane in trimethyloctylphosphonium bis(2,4,4trimethylpentyl) phosphinate was investigated by Prausnitz and co-workers. ${ }^{170,171}$

\subsection{Applications in synthesis}

Ionic liquids can be used either as solvents or catalysts in chemical reactions. One of the most studied transformations has been the insertion (cycloaddition) of $\mathrm{CO}_{2}$ in epoxide rings to afford cyclic carbonates. In this field, the use of ILs and related catalysts such as choline chloride-metal halide mixtures was reviewed by Kerton and co-workers. ${ }^{172}$ Galvan et al. evaluated the use of halide-free PILs as catalysts, using salts having weak organic acid anions, under solvent free conditions. ${ }^{173}$ The authors proposed a catalyst decomposition mechanism in order to explain the deactivation of the catalytic system. Similarly Brennecke, Schneider and co-workers studied the competing reactions of $\mathrm{CO}_{2}$ with cations and anions in azolide PILs (Fig. 6). ${ }^{174}$ The work shows that careful consideration of both physical properties and chemical reactivity of PILs is needed.

Bifunctional phosphonium salts, bearing an alcoholic function on the phosphonium cation, were synthesized and tested by Werner and Büttner (Fig. 6). ${ }^{175}$ The hydrogen-bond donating function led to a synergistic effect accelerating the catalytic reaction.

Sheng-Lian and co-workers prepared functionalized PILs bearing carboxylic, alcoholic or amino groups as catalysts for the cycloaddition to epoxides (Fig. 6). ${ }^{176}$ In order to obtain easily recyclable catalysts, the same authors developed polymer-grafted asymmetrical di-cationic PILs ${ }^{177}$ and chitosan-grafted PILs. ${ }^{178}$ A study by Soares and co-workers demonstrated that octadecyltriphenylphosphonium iodide acted as an activator of silanol groups in $\mathrm{scCO}_{2}$ to increase the grafting density of silane agents on silica. ${ }^{179}$

Selva and co-workers described the application of the basic $\left[\mathrm{P}_{1888}\right]\left[\mathrm{OCOOCH}_{3}\right]$ ionic liquid as catalyst for the transesterification reaction of dimethylcarbonate and benzyl alcohol. ${ }^{180}$ The procedure they 


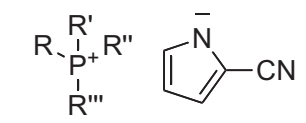

$R, R^{\prime}, R^{\prime \prime}, R^{\prime \prime \prime}=$ alkyl

Ref. 174<smiles>[Y]C(C)C(C)CO</smiles>

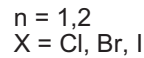

Ref. 175

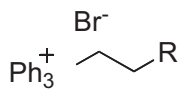

$\mathrm{R}=\mathrm{COOH}, \mathrm{OH}, \mathrm{NH}_{2}, \mathrm{CH}_{3}, \mathrm{H}$

Ref. 176

Fig. 6 Structures of PILs described throughout ref. 174-176.

developed allows the efficient preparation of dibenzylcarbonate. The same research group developed a procedure for the transesterification of dialkyl carbonates with diols catalysed by carbonate $\left[\mathrm{P}_{1888}\right] .{ }^{181}$ Using these catalysts, the authors focused mainly on the competition between cyclic carbonates and linear dicarbonate products.

Zlotin and Vasil'ev studied the influence of ionic liquids on the palladium-catalyzed reaction between diethyl malonate and allyl acetate. ${ }^{182}$ The presence of 1,3-dialkyl-imidazolium ionic liquids afforded the monoallylation product, while 1,2,3-trialkylimidazolium or quaternary ammonium/phosphonium salts promoted diallylation. PILs were also investigated as reaction solvents. Mason and co-workers used $\left[\mathrm{P}_{66614}\right]\left[\mathrm{NTf}_{2}\right]$ as the solvent for a Pd salt-catalysed Suzuki-Miyaura coupling in the presence of gramine-based $\mathrm{N}$-substituted phosphines as ligands. ${ }^{183} \mathrm{~A}$ biphasic ionic liquid/water system outperformed catalysis in neat ionic liquid and provided higher yields at lower temperatures. Yang et al. investigated the synthesis of benzylsalicylate using a dual-site phase transfer catalyst in a triphasic system obtained by mixing the reactant benzyl bromide, aqueous salicylate and $\left[\mathrm{P}_{44414}\right]\left[\mathrm{CH}_{3} \mathrm{SO}_{3}\right] .{ }^{184,185}$ The influence of different ionic liquid media on the addition of hydroxylamine to nitriles was investigated by Voros et al. ${ }^{186}$ The same research group showed that the application of specific imidazolium, phosphonium and quaternary ammonium based ionic liquids prevented the formation of amide side-product. ${ }^{187}$ Tetrabutylphosphonium Brønsted acidic ionic liquids were used to obtain thermoregulated phase-separable reaction systems for the hydroxyalkylation of phenol with formaldehyde to bisphenol F. ${ }^{188}$ In the field of biotechnology, a protocol for the enzymatic hydrolysis of rice straw was developed by Yang and Fang. ${ }^{189}$ $\left[\mathrm{P}_{66614}\right]\left[\mathrm{C}_{9} \mathrm{H}_{19} \mathrm{COO}\right]$ was used as the solvent during an ultrasound mediated pre-treatment.

\subsection{Extraction and separation technologies based on PILs}

Ionic liquid-based multiphasic systems have elicited a great interest in the field of extraction and separation technologies. Aimed at developing guidelines for efficient processes, theoretical studies as well as phase diagrams for multiphasic systems were investigated in detail. Experimental and theoretical studies were performed by Rabari et al. on the use of phosphonium-based PILs (trihexyl(tetradecyl)phosphonium dicyanamide $\left[\mathrm{P}_{66614}\right]\left[\mathrm{C}(\mathrm{CN})_{2}\right]$ and trihexyl(tetradecyl)phosphonium decanoate $\left.\left[\mathrm{P}_{66614}\right][\mathrm{DEC}]\right)$ for biobutanol removal from fermentation broth. ${ }^{190}$ Coutinho and co-workers reported phase diagrams for a series of ionic 
liquid-based aqueous biphasic systems. ${ }^{191}$ The investigated PILs were $\left[\mathrm{P}_{4444}\right]$ chloride and bromide, $\left[\mathrm{P}_{1444}\right]\left[\mathrm{CH}_{3} \mathrm{SO}_{4}\right]$ and $\left[\mathrm{P}_{1 i(444)}\right][\mathrm{Tos}]$. Padró et al. measured the partition coefficients of several organic compounds, between water and ionic liquids such as $\left[\mathrm{P}_{66614}\right] \mathrm{Cl},\left[\mathrm{P}_{66614}\right] \mathrm{Br}$, $\left[\mathrm{P}_{66614}\right]\left[\mathrm{NTf}_{2}\right]$ and $\left[\mathrm{P}_{66614}\right]\left[\mathrm{C}(\mathrm{CN})_{2}\right] .{ }^{192}$ In particular, the latter PIL was immobilised in alginate capsules and used for the removal of $\mathrm{Cd}(\mathrm{II})$ from $\mathrm{HCl}$ aqueous solutions. ${ }^{193}$ In a study by Soto and co-workers, the liquid liquid equilibria of a ternary system comprising water, $n$-dodecane and $\left[\mathrm{P}_{66614}\right]\left[\mathrm{Ntf}_{2}\right]$ were determined. Also, density, viscosity and interfacial tension of the involved phases were investigated. ${ }^{194}$ Experimental values of gas solubility of hydrofluorocarbons $\left(\mathrm{CHF}_{3}, \mathrm{CH}_{2} \mathrm{~F}_{2}\right.$ and $\left.\mathrm{CH}_{3} \mathrm{~F}\right)$ in $\left[\mathrm{P}_{66614}\right] \mathrm{Cl},\left[\mathrm{P}_{1444}\right]\left[\mathrm{CH}_{3} \mathrm{OSO}_{3}\right]$ and $\left[\mathrm{P}_{2444}\right]\left[\left(\mathrm{C}_{2} \mathrm{H}_{5} \mathrm{O}\right)_{2} \mathrm{PO}_{2}\right]$ were determined by Sousa and co-workers. ${ }^{195} \mathrm{~A}$ comparison between the Cubic plus Association equation of state and the regular-solution theory modelling was performed on the basis of the experimental measurements. Ramalingam and co-workers evaluated the performance of DES in the extractive denitrification of liquid fuels by the conductor-like screening model for real solvents. ${ }^{196}$ PDES gave higher capacities, but lower selectivities. In the field of fuel desulfurisation, Domanska and Wlazlo investigated the effect of the cation and anion of many other ionic liquids, including PILs, on desulfurization of model fuels. ${ }^{197}$ Dharaskar $e t$ al. focussed on the use of $\left[\mathrm{P}_{66614}\right]$ [bis(2,2,4-trimethylpentyl) phosphinate], for the extraction of benzothiophene from $n$-dodecane as fuel model. ${ }^{198}$ Coutinho's group has been very active in the field of extraction of organic compounds by ILs. Of note were the study of (i) aqueous micellar two-phase systems with PILs as co-surfactants for the selective extraction of (bio)molecules. ${ }^{199}$ and (ii) the application of several ILs based on ammonium, imidazolium and phosphonium cations for complete removal of textile dyes from aqueous media. ${ }^{200}$

Another remarkable topic is the extraction of metals from aqueous solution by using ILs. Binnemans' group reported several studies on the subject. Among them, interesting investigations were focused on the dissolution of metal oxides in an acid-saturated $\left[\mathrm{P}_{66614}\right] \mathrm{Cl}$, followed by selective stripping of the dissolved metal ions to an aqueous phase. This was a new iono-metallurgical approach for the processing of metals in ionic liquids. ${ }^{201}$ Other applications include the development of a fluorine-free solvent for the extraction of europium(III) and other trivalent rare earth ions using trihexyl(tetradecyl)phosphonium $N, N, N^{\prime}, N^{\prime}$-tetra(2-ethylhexyl)malonate, $\left[\mathrm{P}_{66614}\right][\mathrm{MA}]$ diluted in $\left[\mathrm{P}_{66614}\right]\left[\mathrm{NO}_{3}\right]^{202}$ and bis(2-ethylhexyl)diglycolamic acid (DEHDGA) dissolved in $\left[\mathrm{N}_{8888}\right]$ and $\left[\mathrm{P}_{66614}\right]$ dodecylsulfate. ${ }^{203}$ Also of note is the use of mutually immiscible ILs such as 1-ethyl-3-methylimidazolium chloride and $\left[\mathrm{P}_{66614}\right]$ bis(2,4,4-trimethylpentyl) phosphinate to extract rare earths, ${ }^{204}$ the development of a process using $\left[\mathrm{P}_{66614}\right]\left[\mathrm{NO}_{3}\right]$ to extract rare earths and separate them from nickel or cobalt, ${ }^{205}$ and the use of $\left[\mathrm{P}_{66614}\right] \mathrm{Cl}$ for selective extraction and recycling of metals from nickel metal hydride batteries ${ }^{206}$ and rare-earths from NdFeB magnets. ${ }^{207}$ Extraction of rare earth ions was also studied by Matsumiya et $a .^{208}$ using tri- $n$-butylphosphate in combination with $\left[\mathrm{P}_{2225}\right][\mathrm{TFSA}]$. The latter PIL was proposed as solvent for direct 
electrodeposition of the recovered metals. Chiappe and co-workers investigated the extraction of $\mathrm{Cu}(\mathrm{II}), \mathrm{Zn}$ (II), $\mathrm{Co}(\mathrm{II}), \mathrm{Ni}$ (II) and $\mathrm{Pb}$ (II) using PILs. ${ }^{209}$ Remarkably, the hydrophobic trioctyl(4-vinylbenzyl) phosphonium chloride, $\left[\mathrm{P}_{888(4-\mathrm{VB})}\right] \mathrm{Cl}$, proved highly selective for the removal of $\mathrm{Pb}(\mathrm{II}), \mathrm{Cu}(\mathrm{II}), \mathrm{Zn}$ (II). Castillo et al. reported a study of the extraction of $\mathrm{Cu}$ (II) by PILs from simulated liquid mining waste. ${ }^{210} \mathrm{Hg}$ (II) removal from $\mathrm{HCl}$ solutions was investigated by Navarro and co-workers using of $\left[\mathrm{P}_{66614}\right] \mathrm{Cl}$ impregnated onto Amberlite XAD- $7^{211}$ and $\mathrm{Bi}(\mathrm{III}) .{ }^{212}$ The same IL impregnated on silica was evaluated for $\mathrm{Cs}^{+}$adsorption by Negrea et $a .^{213}\left[\mathrm{P}_{66614}\right] \mathrm{Cl}$, along with imidazolium ILs, was also impregnated onto styrenedivinylbenzene grafted with aminoethylaminomethyl groups for the adsorption of thallium and strontium from aqueous solutions. ${ }^{214}$ IL-based microextraction techniques were also studied for analytical applications, including trace-element analysis. The subject was reviewed by Martinis, Berton and Wuilloud. ${ }^{215}$ Gao and co-workers also developed an IL-assisted liquid-liquid microextraction process in which the solidification of floating organic droplets allowed the preconcentration and analysis of seven benzoylurea insecticides in fruit juices. ${ }^{216}$ In this method, 1-dodecanol and $\left[\mathrm{P}_{66614}\right]\left[\mathrm{PF}_{6}\right]$ were used as extractants.

\subsection{Electrochemical applications}

The high conductivity, thermal stability and wide electrochemical window of PILs and ILs allow remarkable applications of such compounds in the electrochemistry field. Tsunashima et al. prepared and characterised PILs derived from trimethylphosphine with $\left[\mathrm{NTf}_{2}\right]^{-}$and bis(fluorosulfonyl)amide $\left([\mathrm{FSA}]^{-}\right.$) anions. ${ }^{217}$ Such anions, particularly FSA, imparted relatively low melting point, high conductivity and showed a larger redox response of lithium. The use of dimethylacetamide and triethyl(2-methoxyethyl)phosphonium bis(trifluoromethylsulfonyl) imide was investigated by Kim and co-workers as protective additives for high voltage $\mathrm{LiNi}_{0.5} \mathrm{Mn}_{1.5} \mathrm{O}_{4}$ cathode materials. ${ }^{218}$ In a study by Baldo et al., $\left[\mathrm{P}_{66614}\right]\left[\mathrm{NTf}_{2}\right]$ was used to increase the conductivity of olive oil in order to run cyclic voltammetry in the vegetable oil using ferrocene as probe molecule. ${ }^{219}$ The same PIL was used as medium for the passivation of AA5083 aluminium alloy by Huang and co-workers. ${ }^{220}$ PILs are also useful for the electrochemical reduction of oxygen. In a paper by Gonzalo et al., $\left[\mathrm{P}_{66614}\right][\mathrm{Cl}] /$ ethylene glycol mixtures demonstrated better oxygen reduction performance than mixtures containing water or methanol in terms of onset potential and current density. ${ }^{221}$ The same research group performed electrochemical investigations on oxygen reduction in the presence of bis(trifluoromethylsulfonyl)imide and dicyanamide $\left[\mathrm{P}_{66614}\right]$ ILs. $^{222}$ The stability of the cation in the presence of superoxide and peroxide species was demonstrated by NMR. Compton and co-workers were able to "trap" superoxide ions by using $\left[\mathrm{P}_{66614}\right]\left[\mathrm{NTf}_{2}\right]^{223}$ Acidic protons of alkylphosphonium groups were rapidly abstracted by superoxide ions, simplifying the amperometric detection of oxygen under humid conditions. Terasawa and Asaka evaluated ILs as components of gel electrodes and electrolytes for poly(vinylidene fluoride-co-hexafluoropropylene) 
(PVdF-HFP)-based actuators containing single-walled carbon nanotubes. ${ }^{224}$ Ion size, self-diffusion coefficient and ion transport in the electrodes and electrolyte were critical aspects to achieve low-voltage electroactive polymer actuators. Silica particles prepared by a sol-gel process in the presence of different PILs were prepared and characterized by Marins et al. ${ }^{225}$ It was demonstrated that the confinement of $\left[\mathrm{P}_{1 i(444)}\right]$ tosylate, $\left[\mathrm{P}_{44414}\right]$ dodecylbenzene-sulfonate and $\left[\mathrm{P}_{66614}\right]$ bis-2,4,4-(trimethylpentyl)-phosphinate inside the silica particles had a strong influence on the performance of such materials in electrorheological fluids. Ionkin et al. investigated several novel cationic phosphonium dispersants in the preparation of conductive silver pastes for photovoltaic applications. ${ }^{226}$ Tetralkyl phosphonium additives incrementally improved electrical parameters and led to less emitter damage and increased efficiency. Use of ionic liquids for battery technologies is fully established, particularly water saturated $\left[\mathrm{P}_{66614}\right] \mathrm{Cl}$ is a promising electrolyte for magnesium-air batteries. The rôle of water was investigated by Yan et $a{ }^{227}$ The presence of active protons and/or oxygen-donor groups were key features for the development of IL-based electrolytes for magnesiumair cells. In the field of lithium batteries, Howlett and co-workers analysed the use of an organic ionic plastic crystal electrolyte based on triisobutyl(methyl)phosphonium bis(fluorosulfonyl)imide $\left(\left[\mathrm{P}_{1 i(444)}\right][\mathrm{FSI}]\right) .{ }^{228}$ Tafur and Romero reported on the electrical and spectroscopic characterization of PVdF-HFP and $\mathrm{NTf}_{2}$ ILs-based gel polymer electrolyte membranes. ${ }^{229}$ Several ILs, particularly $\left[\mathrm{P}_{66614}\right]\left[\mathrm{NTf}_{2}\right]$, were tested to explore their influence of zinc salts.

\subsection{Miscellaneous applications}

Phosphonium ionic liquids (PILs) were investigated as lubricants or lubricant additives. In a paper by the $\mathrm{Qu}$ group, $\left[\mathrm{P}_{4444}\right]$ - and $\left[\mathrm{P}_{66614}\right]$-based ionic liquids were evaluated as lubricant antiwear additives. In the presence of different anions, the ranking of effectiveness in wear protection was organophosphate $>$ carboxylate $>$ sulfonate. ${ }^{230}$ The same research group also reported a comparison of the tribological behavior of steel-steel and $\mathrm{Si}_{3} \mathrm{~N}_{4}$-steel contacts in lubricants with zinc dialkyldithiophosphate or $\left[\mathrm{P}_{66614}\right]$ [bis(2-ethylhexyl) phosphate] as additives. ${ }^{231}$

Biodegradable tributyl(methyl)phosphonium diphenylphosphate $\left(\left[\mathrm{P}_{1444}\right][\mathrm{DPP}]\right)$ was tested as an antiwear additive by Forsyth and coworkers. ${ }^{232}$ It was observed that such an IL had a better film-forming ability than the commonly used amine-phosphate. Fernandez and coworkers described the use of $\left[\mathrm{P}_{2444}\right]\left[\left(\mathrm{CH}_{3} \mathrm{CH}_{2} \mathrm{O}\right)_{2} \mathrm{PO}_{2}\right]$ (A) and $\left[\mathrm{P}_{66614}\right]\left[\left(\mathrm{C}_{2} \mathrm{~F}_{5}\right)_{3} \mathrm{PF}_{3}\right]$ (B) as lubricant additives and/or neat lubricants. ${ }^{233}$ PIL A showed the best antifriction ability, whereas PIL B showed better wear results. Overall, both friction and wear were improved with the use of blends containing PIL A. The same research group evaluated the tribological behaviour for two ILs based on the $\left[\left(\mathrm{C}_{2} \mathrm{~F}_{5}\right)_{3} \mathrm{PF}_{3}\right]$ anion and $\left[\mathrm{C}_{4} \mathrm{dmim}\right]$ or $\left[\mathrm{P}_{66614}\right]$ cations as neat lubricants. ${ }^{234}$ These PILs always showed better lubricating properties than imidazolium-based IL in terms 
of both friction coefficient and wear volume. Gabler and co-workers investigated the lubrication mechanism of tributylmethylphosphonium dimethylphosphate as an additive in alkylborane-imidazole complexes. $^{235}$ The same authors also reported X-ray photoelectron spectroscopic studies to examine the influence of cationic moieties on the tribolayer constitution of $\left[\mathrm{NTf}_{2}\right]$-based PILs. ${ }^{236}$

ILs are known to stabilise metal nanoparticles (NPs) by electrostatic interaction combined with steric protection. Zvereva and co-workers reported a study based on infrared spectroscopy and density functional theory to investigate the solvation and stabilization of palladium NPs in phosphonium-based ionic liquids. ${ }^{237}$ Stucky and co-workers described a general approach for the synthesis of micro-/nano-structured metal chalcogenide semiconductors from elemental precursors. ${ }^{238}$ The excellent solubility of sulfur, selenium, and tellurium in $\left[\mathrm{P}_{4444}\right] \mathrm{Cl}$ promoted fast reactions between chalcogens and various metal powders upon microwave heating, giving crystalline products.

A significant application was reported by Tan et $a l .^{239}$ They prepared modified gold nanoparticles decorated with $\left[\mathrm{P}_{66614}\right] \mathrm{Cl}$ on their surface. In the presence of As(III), the nanoparticle solution turned from red to blue. This was due to the selective interaction of the ionic liquid with As(III). With the colorimetric probe, authors developed a protocol for naked eye speciation test of $\mathrm{As}(\mathrm{III})$ and $\mathrm{As}(\mathrm{v})$ at levels below the World Health Or-

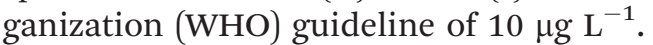

High viscosity, thermal stability, and negligible vapor pressure of ILs are promising properties for the preparation of stationary phases for gas chromatography. González-Álvarez et al. used a chemometric approach to characterise three IL types with hexacationic imidazolium, polymeric imidazolium, and phosphonium cationic cores, using a range of anions. ${ }^{240}$ In a study by Anderson and co-workers, imidazolium based ILs as well as $\left(\left[\mathrm{P}_{66614}\right]\left[\mathrm{FeCl}_{4}\right]\right)$ and $\left[\mathrm{P}_{66614}\right]\left[\mathrm{NTf}_{2}\right]$ PILs, were evaluated as stationary phases in comprehensive two-dimensional gas chromatography for the separation of aliphatic hydrocarbons from kerosene. ${ }^{241}$ Burns et al. reported a new method for dissolving cellulose based on the use of mixtures of dimethylformamide with several PILs, including $\left[\mathrm{P}_{66614}\right] \mathrm{Cl},\left[\mathrm{P}_{66614}\right]\left[\mathrm{C}_{9} \mathrm{H}_{19} \mathrm{COO}\right]$, $\left[\mathrm{P}_{66614}\right]\left[\mathrm{C}(\mathrm{CN})_{2}\right],\left[\mathrm{P}_{\mathrm{i}(4,4,4), 1}\right][\mathrm{OTs}],\left[\mathrm{P}_{4444}\right] \mathrm{Cl}$ and $\left[\mathrm{P}_{44414}\right] \mathrm{Cl}^{242}$

PILs were also investigated as modifiers for clays and polymers. McNally and co-workers prepared 1-ethylpyridinium and tri- $n$-butyl(2hydroxyethyl)phosphonium docusate ${ }^{243}$ and investigated the use of such compounds to improve the plasticization and antimicrobial efficacy of medical grade poly(vinylchloride)s (PVCs). New materials - obtained by impregnation of PVC with the two ILs - were characterised in terms of antimicrobial activity and glass transition temperature. Livi et al. studied the factors affecting the structure and properties of PILs based on $\left[\mathrm{P}_{66614}\right]$ and several anions including chloride, dialkylphosphate and $\mathrm{NTf}_{2}$, in a poly(butylene-adipate-co-terephthalate) matrix. The influence on the water vapour permeability and mechanical properties of the polymer were rationalised. ${ }^{244}$ The same research group also investigated the use of tetraalkylphosphonium and dialkyl imidazolium cations as new surfactant agents for cationic exchange of lamellar silicates. ${ }^{245}$ 
They proposed $\left[\mathrm{P}_{66614}\right]\left[\mathrm{C}(\mathrm{CN})_{2}\right]$ as a functional additive to afford epoxynetworked polymeric materials with improved mechanical properties and a higher thermal stability $\left(>400{ }^{\circ} \mathrm{C}\right){ }^{246}$ Finally, they described epoxynetworked polymeric materials containing $\left[\mathrm{P}_{66614}\right]\left[\left(\mathrm{C}_{2} \mathrm{H}_{5} \mathrm{O}\right)_{2} \mathrm{PO}_{2}\right]$ (diethyl phosphate anion) and $\left[\mathrm{P}_{66614}\right]$ bis-2,4,4-(trimethyl pentyl)-phosphinate. ${ }^{247}$ PILs were also reported as additives for other epoxy resins, ${ }^{248,249} \mathrm{PVC},{ }^{250}$ and polycarbonates. ${ }^{251,252}$ Glas et al. described a process for the end-oflife treatment of PVC that demonstrated how the use of $\left[\mathrm{P}_{4444}\right] \mathrm{Cl}$ allowed the dehydrochlorination and/or dissolution of the chlorinated polymers poly(vinylchloride) (PVC) and chlorinated polyethylene (CPE) ${ }^{253}$ Swelling and shrinking photoresponsive phosphonium-based ionogel microstructures were investigated by Lopez and co-workers. It was found that the $\left[\mathrm{P}_{66614}\right]\left[\mathrm{NTf}_{2}\right]$ ionogel allowed the highest degree of swelling. ${ }^{254,255}$ Deguchi, Kohno and Ohno designed polyelectrolytes derived from tributyl-n-alkylphosphonium 3-sulfopropylmethacrylate-type IL monomers. Based on these compounds, chemically cross-linked polyelectrolyte gels were prepared, showing LCST-type phase changes. ${ }^{256}$ Fortuny et al. reported an investigation on supported liquid membranes with Aliquat 336, $\left[\mathrm{P}_{66614}\right] \mathrm{Cl}$ and $\left[\mathrm{P}_{44414}\right] \mathrm{Cl}$ as carriers to exchange $\mathrm{Cl}^{-}$for $\mathrm{HCO}_{3}{ }^{-}$in water purification. ${ }^{257}$ Warner and co-workers designed disposable photonic sensor arrays based on a series of twelve $\left[\mathrm{P}_{66614}\right]$ ILs, bearing anionic dyes as counter ion. The arrays were sensitive to $\mathrm{pH}$ values, as well as acidic and basic vapours. ${ }^{258}$ Nine PILs and one imidazolium-based IL were examined as additives and coal oxidation inhibitors by Zhang, Jiang and Hardacre. Tributylethylphosphonium diethylphosphate $\left(\left[\mathrm{P}_{2444}\right][\mathrm{DEP}]\right)$ was found to be the most effective. ${ }^{259} \mathrm{Mg}$ alloys are attractive candidate materials for biodegradable stents, although $\mathrm{Mg}$ alloys generally undergo rapid localized corrosion in the body. Forsyth and co-workers investigated a new surface coating for Mg alloy AZ31, based on biocompatible $\left[\mathrm{P}_{1444}\right]$ diphenyl phosphate. ${ }^{260}$ Photopolymerization coupled with mask projection micro-stereolithography was used by Long and co-workers to generate various 3D printed polymerized PILs with low UV light intensity and high digital resolution. ${ }^{261}$

\section{P-ylides (phosphoranes)}

Phosphoranes or phosphorus ylides are an extremely useful class of compounds in synthetic chemistry. Several recent studies have been published on the preparation, properties, and applications of ylides as reactants or ligands. Also, mechanistic investigations on the reactivity as well as on the antibacterial, antifungal and/or antitumoral activity of such compounds have been detailed.

\subsection{Preparation, structural properties and mechanistic investigations}

The preparation and characterization of stable ylides have been recently described in various examples. Two remarkable syntheses of phosphorus ylides were reported by the condensation of electron-poor acetylenes including dimethylacetylene dicarboxylate with triphenylphosphine (Fig. 7). ${ }^{262,263}$ The reactions of nucleophilic active 
phosphacumulene, phosphaallene, and stable phosphonium ylides with different substrates were investigated by Said, Zeid and co-workers (Fig. 7). ${ }^{264}$ This approach allowed the preparation of phosphanylidene cyclobutanones, oxaphosphetanes, oxaphosphinines, azaphosphetidenes, and pyridazines. The cytotoxic activity of all these compounds was evaluated against human cervical and breast carcinoma cell lines. Soliman et al. reported the reaction of 4-azido-2-oxo- $2 \mathrm{H}$-chromene-3carbaldehyde with phosphacumulenes, yielding the corresponding phosphanylidene-aziridines and chromeno-pyrolo-triazoles. Also, the reaction with hexaphenylcarbodiphosphorane afforded a phosphanylidenechromeno-triazinone (Fig. 7). ${ }^{265}$

Han, Sheng and Yan described the synthesis of triphenylphosphanylidene spiro[cyclopentane-1,3'-indolines] and spiro[cyclopent[2]ene1,3'-indolines] via three-component reactions of triphenylphosphine, isatylidene malononitrile(ethyl cyanoacetate) and but-2-ynedioate or hex-2en-4-ynedioate, respectively (Fig. 7). ${ }^{266}$

Chuang and co-workers reported the synthesis of fluorescent $\gamma$-lactams possessing an $\alpha$-phosphorus ylide moiety. The investigated multicomponent reaction gave $\gamma$-lactams in one pot, using different phosphines (Fig. 7). ${ }^{267} \mathrm{~A}$ very interesting study by Petz and Neumüller was focused on the alkylation of $\mathrm{Ph}_{3} \mathrm{PCHP}(\mathrm{O}) \mathrm{Ph}_{2} \cdot{ }^{268}$ The reaction proceeded exclusively at the carbon atom, but uptake of a proton from various solvents was also observed in the presence of a Lewis acid. Solomon, Wright and co-workers attempted the synthesis of the ylide dianion $\left[2,4,6-\mathrm{Me}_{3} \mathrm{C}_{6} \mathrm{H}_{2} \mathrm{P}-(\mathrm{CHR})_{3}\right]^{2-}$ (where $\mathrm{R}=\mathrm{H}$ or Me). The desired compound was not formed, since a quantitative 1,3-sigmatropic rearrangement took place, leading to new benzylic phosphonium salts (Fig. 7). ${ }^{269}$

Detailed characterisation and quantum-mechanical calculations were also reported for new ylides. Habibi-Khorassani et al. described a ${ }^{1} \mathrm{H}$ NMR spectroscopic investigation of the kinetics of formation of the $Z$ and $E$ isomer equilibrium mixture for a stable phosphorus ylide containing a 2-benzoxazolinone group. ${ }^{270} \mathrm{~A}$ computational study of Yu and co-workers offered a detailed analysis of Lewis base-catalyzed reactions of allenoates as well as of the chemical properties of their adducts with different Lewisbases, including $\mathrm{PBu}_{3}, \mathrm{PPh}_{3}$, and $\mathrm{P}\left(\mathrm{NMe}_{2}\right)_{3}{ }^{271} \mathrm{Ji}$ et al. investigated the cooperativity between the hydrogen/halogen bonds and $\mathrm{NH}_{3}$ with $\mathrm{PPh}_{3}=\mathrm{CH}_{2}$ by performing quantum-mechanical (MP2 and QTAIM) computational studies on the adducts of the type $\mathrm{XH} / \mathrm{XCl} \cdots \mathrm{CH}_{2} \mathrm{PH}_{3} \cdots \mathrm{NH}_{3}$ $\left(\mathrm{X}=\mathrm{F}, \mathrm{N}_{3}, \mathrm{CN}, \mathrm{CCCN}, \mathrm{CCF}\right) .{ }^{272}$ The reaction of perfluoroalkyl thioamides with trimethyl phosphine, trimethyl phosphite, and tris(dimethylamino)phosphine was analysed by quantum-chemical (DFT and MP2) calculations by Rozhenko and co-workers. ${ }^{273}$ The suggested mechanism involved the formation of a phosphorus ylide, which in turn underwent a migration of fluorine from carbon to phosphorus.

\subsection{Applications in synthesis}

Wittig and Horner-Wadsworth-Emmons olefinations are among the most common and widely used applications of phosphorus ylides in 

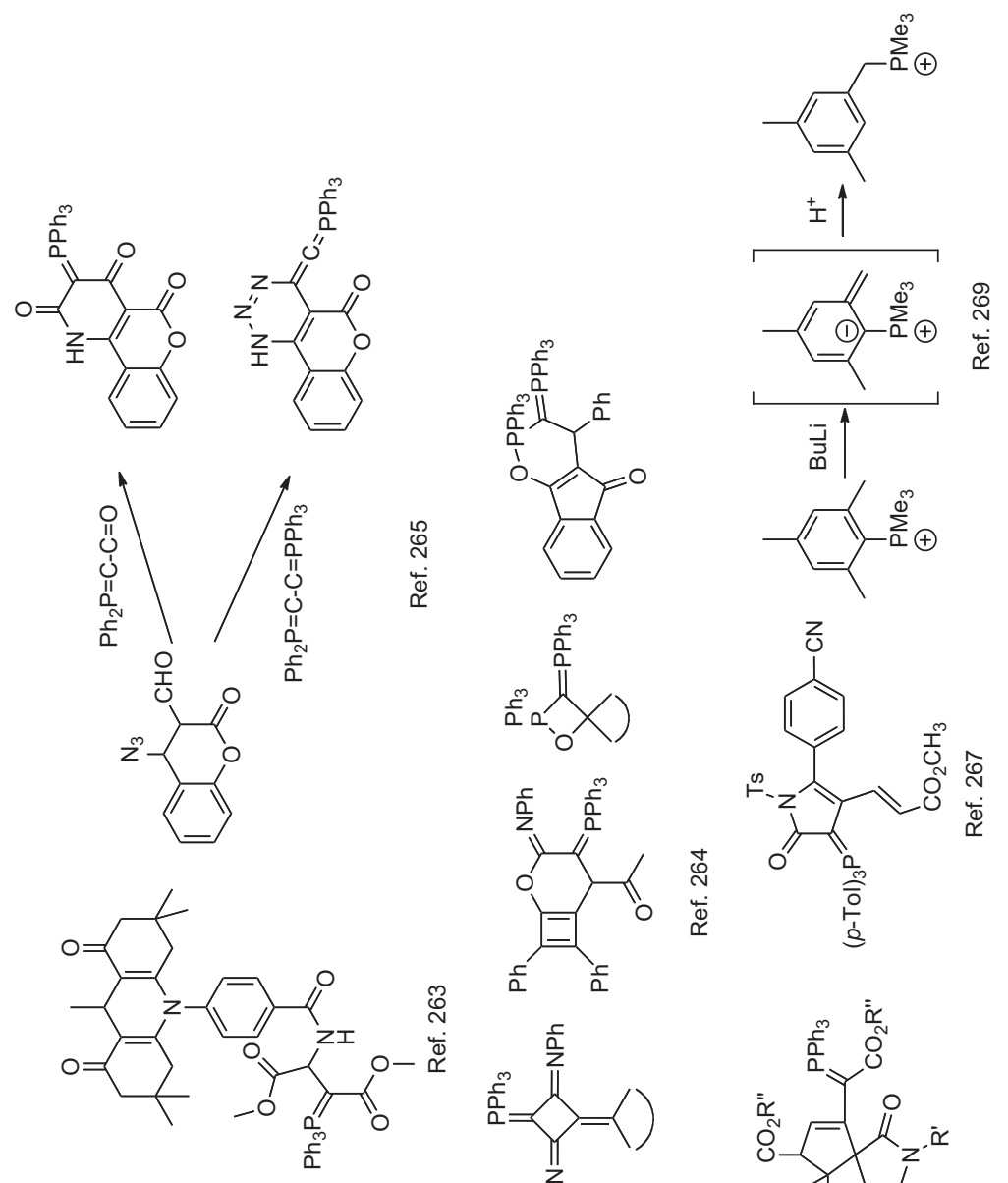

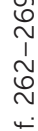
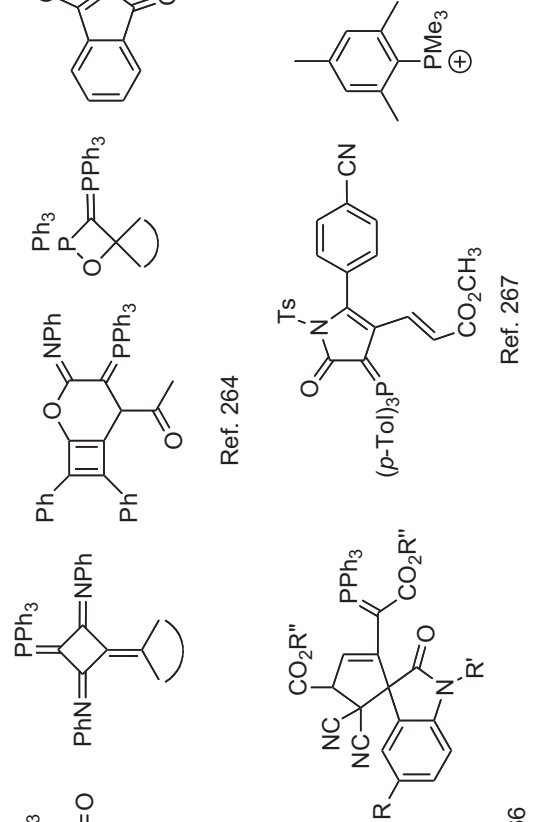

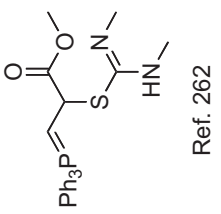
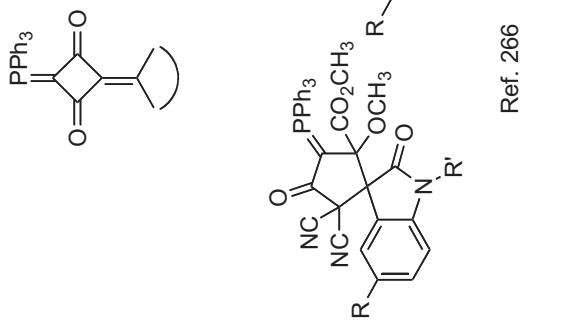
synthesis. A review by Jasem, El-Esawi and Thiemann focused on the use of stabilised and semi-stabilised phosphoranes and phosphonates under non-classical conditions. ${ }^{274}$ The mechanism of the Wittig reaction of anisaldehyde with a stabilized ylide was studied by Singleton and coworkers. ${ }^{275}$ A combination of ${ }^{13} \mathrm{C}$ kinetic isotope effects, conventional calculations, and molecular dynamics calculations in a cluster of 53 THF molecules was considered, in order to establish if the reaction proceeds through a concerted or a two-step processes. The authors concluded that even if the isotope effects supported the formation of a betaine intermediate, nonetheless energetically perfect calculations employing any of the standard equilibrium methods cannot unambiguously assign mechanisms.

The O'Brien group has described a catalytic Wittig reaction and extended the applicability of the procedure to semistabilized and nonstabilized ylides, involving the use of a masked base, sodium tert-butyl carbonate. ${ }^{276}$ Huang et al. reported a procedure for the Wittig olefination in the absence of additional base. The reaction occurred in the presence of phosphonium salts of the type $\left[\mathrm{Ph}_{3} \mathrm{PCH}_{2} \mathrm{R}\right]\left[\mathrm{BPh}_{4}\right]$ where $\mathrm{R}$ is an electron withdrawing group such as $-\mathrm{CN},-\mathrm{COOEt}$, or $-\mathrm{C}(\mathrm{O}) \mathrm{Ph}^{277}$ Tang and co-workers investigated an ylide-initiated tandem cyclization based on $\gamma$-dialkylation of allylic ylides. The reaction yielded a series of [3.3.0] oxabicyclic dienes in high yields and excellent diastereoselectivity (Scheme 12). ${ }^{278}$

$\mathrm{A} \mathrm{Bu}_{3} \mathrm{P}$-mediated efficient synthesis of multi-functional alkenes was described by Lin and co-workers. ${ }^{279}$ In situ-generated zwitterionic intermediates underwent proton-exchange affording ylide intermediates which were trapped with aldehydes. The overall reaction provided target olefins with complete $E$-stereoselectivity. Werner et $a .^{280}$ reported the first microwave-assisted catalytic Wittig reaction. Tsuji and co-workers detailed the synthesis of a chiral phosphonium salt which provided a new Wittig reagent to prepare $\alpha$-substituted alaninol derivatives. ${ }^{281}$ The result offered a new approach to the synthesis of chiral S1P1 agonists. Many other applications of the Wittig reaction were reported in the literature; they include for example, the synthesis of eushearilide, ${ }^{282}(+)$-chloriolide, ${ }^{283}$ 1,3-di-O-cinnamoyl-glycerol, ${ }^{284}$ locked retinals, ${ }^{285}$ and $(+)$ monanchorin. ${ }^{286}$ The Wittig protocol was used also for the preparation of polymers $^{287}$ and donor-acceptor 1,4-fluorenylene chromophores. ${ }^{288}$ The combination of (chlorodifluoromethyl)trimethylsilane and $\mathrm{PPh}_{3}$ for the synthesis of gem-difluoroolefins from carbonyl compounds was reported by $\mathrm{Hu}$ and co-workers. ${ }^{289}$ The procedure proved more

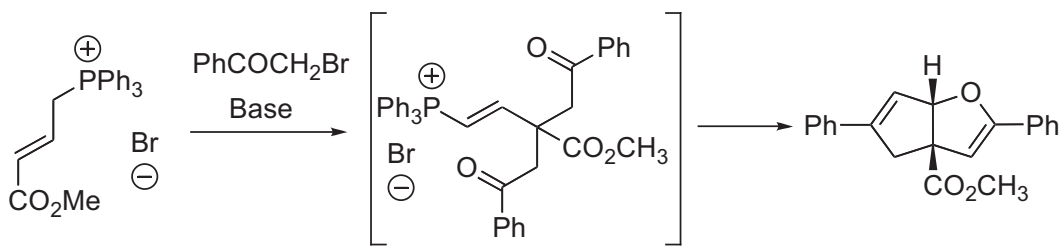

Scheme 12 Double $\gamma$-dialkylation to oxa-bicyclic[3.3.0] dienes. 
<smiles>Cc1c(F)c(F)c(/C=C/C(=O)O)c(F)c1F</smiles>

Scheme 13 Methyl transfer to functionalized polyfluoroarenes.

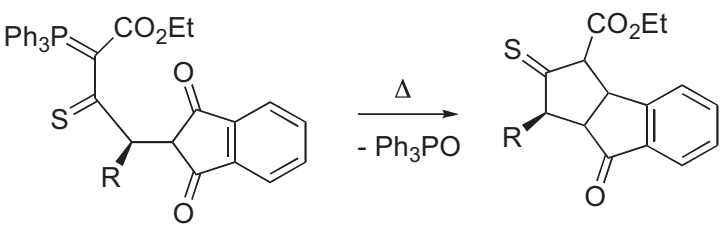

Scheme 14 Pyrolysis of phthalimido thioxo-stabilised ylides.

efficient than the use of (bromodifluoromethyl)trimethylsilane and (trifluoromethyl)trimethylsilane. Li et al. demonstrated that the same goal was also achieved with difluoromethyltriphenylphosphonium bromide. ${ }^{290}$ Dilan and co-workers described the use of the air-stable reagent difluoromethylene phosphabetaine for the nucleophilic difluoromethylation of reactive Michael acceptors, aldehydes, and azomethines. ${ }^{291}$

An unprecedented alkyl transfer from phosphonium ylides to polyfluoroarenes was reported by Yang, Wu and co-workers. ${ }^{292}$ The reaction proceeded with a high regioselectivity under very mild conditions; moreover, it allowed the introduction of a variety of alkyl groups to the para position of functionalized polyfluoroarenes (Scheme 13).

Aikten et al. described the pyrolysis of chiral phthalimido thioxostabilised phosphonium ylides. ${ }^{293}$ Such compounds were prepared from $(S)$-alanine and $(S)$-phenylalanine, and underwent an intramolecular Wittig reaction leading to pyrrolo[2,1- $a$ ]isoindol-5-one-2-thiones, rather than the expected $P$ to $S$ migration of a phenyl group (Scheme 14).

A phosphane-catalyzed $[4+1]$ annulation between nitroalkenes and Morita-Baylis-Hillman carbonates was performed by $\mathrm{He}$ and coworkers. ${ }^{294}$ The authors claimed the in situ formation of an allylic phosphorus ylide as an active intermediate. Allenoates and enones were able to form cyclopentenes via two cycloaddition reactions: they underwent a $[3+2]$ or a $[2+4]$ process in the presence of catalytic phosphines or amines, respectively (Scheme 15). To explain such a different reactivity, Huang, Lankau and $\mathrm{Yu}$, carried out M06-2X/6-31 + $\mathrm{G}^{*}$ calculations to study the role of ylide intermediates. ${ }^{295}$

\subsection{Coordination chemistry}

The use of ylides as ligands in organometallic chemistry is well established and is extremely useful in the preparation of catalysts and catalytic precursors. Prof. Sabounchei's group reported several studies on the synthesis of complexes from $\alpha$-keto-stabilised phosphorus ylides as mono and bidentate ligands. In particular, they focused on palladacycle 


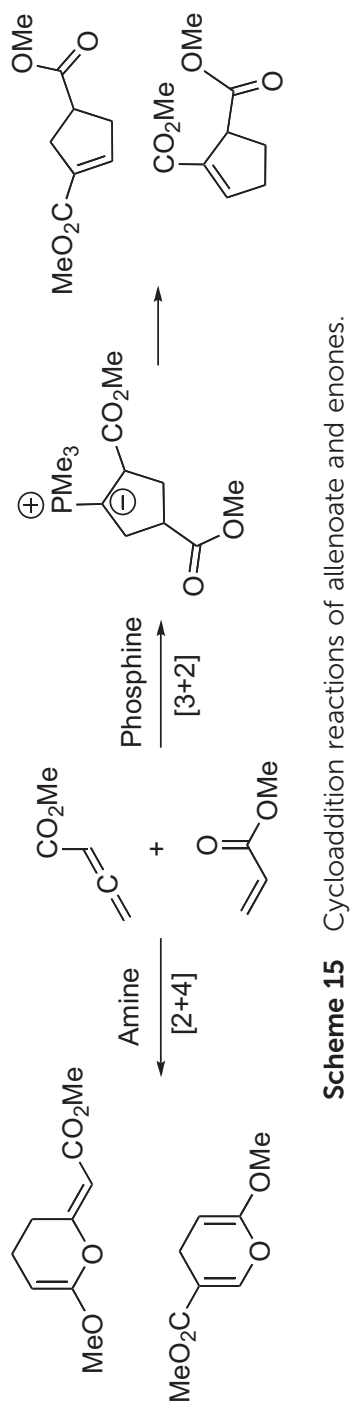


complexes as catalysts for Mizoroki-Heck reactions ${ }^{296}$ and Suzuki/Heck couplings. ${ }^{297}$ The preparation of seven-membered $\operatorname{Pd}(\mathrm{II})$ complexes bearing symmetric bidentate phosphorus ylides was also remarkable. ${ }^{298}$ Other metals such as mercury(II) ${ }^{299,300}$ and copper(I) were investigated for the synthesis of similar complexes. ${ }^{301}$ The antimicrobial activity of these compounds was also evaluated.

Ning and co-workers described substitution reactions using preformed ylides for the preparation of molybdenum complexes bearing triphenylcyclopentadienylide ligands. ${ }^{302}$ Analogous compounds were obtained by Sundermeyer and co-workers using ruthenium as the metal center. ${ }^{303}$ Martschitsch and Schubert reported NMR studies on the reaction of $\left[\left(\kappa^{2}-\right.\right.$ $\left.\mathrm{P}, \mathrm{N})-\mathrm{Ph}_{2} \mathrm{PCH}_{2} \mathrm{CH}_{2} \mathrm{NMe}_{2}\right] \mathrm{PtMe}_{2}$ with either ethyl chloroacetate or benzyl chloride. After a complex series of experiments, the formation of ylide complexes $\mathrm{Pt}\left[\mathrm{CH}_{2}=\mathrm{PPh}_{2}(\right.$ vinyl $\left.)\right]\left(\mathrm{NMe}_{2} \mathrm{R}\right) \mathrm{Me}_{2} \quad(\mathrm{R}=\mathrm{COOEt}$ or $\mathrm{Ph})$ was proved. ${ }^{304}$ Mindiola and co-workers observed that the addition of excess ylide, $\mathrm{H}_{2} \mathrm{CPPh}_{3}$, to bis-aryloxide methyl tantalum complexes of the type $\left[\left(\mathrm{Ar}^{\prime} \mathrm{O}\right)_{2} \mathrm{Ta}\left(\mathrm{CH}_{3}\right) \mathrm{Cl}_{2}\right]$ resulted in the formation of the terminal tantalum methylidene chloride complex $\left[\left(\mathrm{Ar}^{\prime} \mathrm{O}\right)_{2} \mathrm{Ta}=\mathrm{CH}_{2}(\mathrm{Cl})\left(\mathrm{H}_{2} \mathrm{CPPh}_{3}\right)\right]$. $^{305}$ Swarnakar et al. investigated the stabilisation of Group 14 element dihydrides, $\left(\mathrm{GeH}_{2}\right.$ and $\left.\mathrm{SnH}_{2}\right) \cdot{ }^{306}$ They noticed that only the ylide $\mathrm{Ph}_{3} \mathrm{P}=\mathrm{CMe}_{2}$ afforded stable inorganic methylene complexes, demonstrating the utility of this under-explored ligand class. DFT calculations on ylide complexes were also reported. Samiee and Mahdavifar examined the structural and electronic properties of a series of transition metal complexes of bidentate phosphorus ylides of the following general formula $\left[\left(\mathrm{R}_{2} \mathrm{P}\left(\mathrm{CH}_{2}\right)_{n} \mathrm{PR}_{2} \mathrm{C}(\mathrm{H}) \mathrm{C}(\mathrm{O}) \mathrm{R}\right) \mathrm{MX}_{2}\right]{ }^{307}$ A computational study by Xie and co-workers investigated the reactivity of a cationic methylene complex $\left[\left(2,6 \text {-bis(di-tert-butylphosphinito)pyridine) } \operatorname{Ir}\left(\mathrm{CH}_{2}\right)\right]^{+}\right.$with $\mathrm{PMe}_{3} \cdot{ }^{308}$

\section{References}

1 A. V. Salin, A. R. Fatkhutdinov, A. V. Il'in and V. I. Galkin, Int. J. Chem. Kinet., 2014, 46, 206.

2 E. V. Jennings, K. Nikitin, Y. Ortin and D. G. Gilheany, J. Am. Chem. Soc., 2014, 136, 16217.

3 A. Bhunia, T. Kaicharla, D. Porwal, R. G. Gonnade and A. T. Biju, Chem. Commun., 2014, 50, 11389.

4 S. Sasaki, K. Sutoh, Y. Shimizu, K. Kato and M. Yoshifuji, Tetrahedron Lett., 2014, 55, 322.

5 O. Aganova, L. Galiullina, A. Aganov, Y. Shtyrlin, M. Pugachev, N. Shtyrlin and V. Klochkov, Appl. Magn. Reson., 2014, 45, 653.

6 C. R. Chen and Y. C. Lin, Organometallics, 2014, 33, 6408.

7 M. J. Ray, M. Buhl, L. J. Taylor, K. S. A. Arachchige, A. M. Z. Slawin and P. Kilian, Inorg. Chem., 2014, 53, 8538.

8 C. Lopez-Leonardo, R. Raja, F. Lopez-Ortiz, M. Angel del Aguila-Sanchez and M. Alajarin, Eur. J. Org. Chem., 2014, 2014, 1084.

9 S. T. Hemp, A. G. Hudson, M. H. Allen, S. S. Pole, R. B. Moore and T. E. Long, Soft Matter, 2014, 10, 3970.

10 R. J. Ono, S. Q. Liu, S. Venkataraman, W. L. Chin, Y. Y. Yang and J. L. Hedrick, Macromolecules, 2014, 47, 7725. 
11 Z. Y. Song, N. Zheng, X. C. Ba, L. C. Yin, R. J. Zhang, L. Ma and J. J. Cheng, Biomacromolecules, 2014, 15, 1491.

12 S. W. Liang, M. V. O'Reilly, U. H. Choi, H. S. Shiau, J. Bartels, Q. Chen, J. Runt, K. I. Winey and R. H. Colby, Macromolecules, 2014, 47, 4428.

13 F. F. Han, T. D. Wang, J. H. Li, H. Zhang and H. P. Xia, Chem. - Eur. J., 2014, 20, 4363.

14 X. Y. Cao, Q. Y. Zhao, Z. Q. Lin and H. P. Xia, Acc. Chem. Res., 2014, 47, 341.

15 A. K. D. Dimé, C. H. Devillers, H. Cattey and D. Lucas, Dalton Trans., 2014, 43, 14554.

16 A. R. Kenaree, B. M. Berven, P. J. Ragogna and J. B. Gilroy, Chem. Commun., 2014, 50, 10714.

17 S. Pal, P. P. Jana and H. P. Nayek, RSC Adv., 2014, 4, 26902.

18 A. K. Gupta, A. K. Srivastava, I. K. Mahawar and R. Boomishankar, Cryst. Growth Des., 2014, 14, 1701.

19 N. W. Waggoner, B. Saccoccia, I. A. Ibarra, V. M. Lynch, P. T. Wood and S. M. Humphrey, Inorg. Chem., 2014, 53, 12674.

20 I. Galkina, A. Tufatullin, D. Krivolapov, Y. Bakhtiyarova, D. Chubukaeva, V. Stakheev, V. Galkin, R. Cherkasov, B. Buchner and O. Kataeva, CrystEngComm, 2014, 16, 9010.

21 M. Holynska, S. Dehnen, F. Weigend and T. Lis, Inorg. Chim. Acta, 2014, 411, 26.

22 W. Q. Chen, R. K. Huang, X. Z. Lv, Q. Y. Guan, H. Q. Ye, X. P. Liu, L. M. Yang, J. R. Zhou and C. L. Ni, Synth. React. Inorg. Met.-Org. Chem., 2014, 44, 1225.

23 C. M. Donahue, I. K. Black, S. L. Pecnik, T. R. Savage, B. L. Scott and S. R. Daly, Polyhedron, 2014, 75, 110.

24 S. Muromachi, S. Takeya, Y. Yamamoto and R. Ohmura, CrystEngComm, 2014, 16, 2056.

25 A. Fukumoto, P. Paricaud, D. Dalmazzone, W. Bouchafaa, T. T. S. Ho and W. Furst, J. Chem. Eng. Data, 2014, 59, 3193.

26 N. Ye and P. Zhang, Fluid Phase Equilib., 2014, 361, 208.

27 P. Feldhaus, B. Wibbeling, R. Frohlich, C. G. Daniliuc, G. Kehr and G. Erker, Synlett, 2014, 25, 1529.

28 Y. Hasegawa, C. G. Daniliuc, G. Kehr and G. Erker, Angew. Chem., Int. Ed., 2014, 53, 12168.

29 Y. Hasegawa, G. Kehr, S. Ehrlich, S. Grimme, C. G. Daniliuc and G. Erker, Chem. Sci., 2014, 5, 797.

30 J. Mobus, G. Kehr, C. G. Daniliuc, R. Frohlich and G. Erker, Dalton Trans., 2014, 43, 632 .

31 M. H. Holthausen, M. Mehta and D. W. Stephan, Angew. Chem., Int. Ed., 2014, 53, 6538.

32 Y. F. Li, Y. Kang, J. S. Lu, I. Wyman, S. B. Ko and S. N. Wang, Organometallics, 2014, 33, 964.

33 C. Garcia, F. Fuenzalida, D. Ruiz and M. J. Aguirre, J. Appl. Electrochem., 2014, 44, 1345.

34 H. Agarwalla, K. Jana, A. Maity, M. K. Kesharwani, B. Ganguly and A. Das, J. Phys. Chem. A, 2014, 118, 2656.

35 T. Wang, J. J. Liu, H. W. Sun, L. Chen, J. Dong, L. P. Sun and Y. S. Bi, RSC Adv. , 2014, 4, 1864.

36 T. Wang, J. J. Liu, D. S. Zhang and H. W. Sun, RSC Adv., 2014, 4, 44948.

37 S. Heinig, A. Wohl, W. Müller, M. H. Al-Hazmi, B. H. Muller, N. Peulecke and U. Rosenthal, ChemCatChem, 2014, 6, 514.

38 P. O. Lagaditis, P. E. Sues, J. F. Sonnenberg, K. Y. Wan, A. J. Lough and R. H. Morris, J. Am. Chem. Soc., 2014, 136, 1367. 
39 H. Braband, M. Benz, Y. Tooyama and R. Alberto, Chem. Commun., 2014, 50, 4126.

40 S. Dridi, A. Mechria and M. Msaddek, J. Organomet. Chem., 2014, 772, 217.

41 R. R. Dey and S. S. Dhar, Synth. Commun., 2014, 44, 2355.

42 A. R. Hajipour and G. Azizi, RSC Adv., 2014, 4, 20704.

43 S. Kumar, M. R. Ajayakumar, G. Hundal and P. Mukhopadhyay, J. Am. Chem. Soc., 2014, 136, 12004.

44 K. D. Reichl and A. T. Radosevich, Chem. Commun., 2014, 50, 9302-9305.

45 L. H. Zhang, Q. Tang, R. A. Weiss and K. A. Cavicchi, Polym. Chem., 2014, 5, 5492-5500.

46 S. Paul, S. Panda and D. Manna, Tetrahedron Lett., 2014, 55, 2480-2483.

47 S. Y. Ji, Y. M. Sun, H. Zhang, Q. G. Hou and C. Q. Zhao, Tetrahedron Lett., 2014, 55, 5742.

48 K. Yahata, M. Minami, K. Watanabe and H. Fujioka, Org. Lett., 2014, 16, 3680.

49 E. Remond and S. Juge, Chim. Oggi, 2014, 32, 49.

50 S. Shirakawa, K. Koga, T. Tokuda, K. Yamamoto and K. Maruoka, Angew. Chem., Int. Ed., 2014, 53, 6220.

51 R. Kadyrov and D. Hackenberger, Top. Catal., 2014, 57, 1366.

52 Y. S. Kumar, C. Dasaradhan, K. Prabakaran, F. R. N. Khan, E. D. Jeong, E. H. Chung and H. G. Kim, RSC Adv., 2014, 4, 40259.

53 M. K. Lakshman, M. K. Singh, M. Kumar, R. R. Chamala, V. R. Yedulla, D. Wagner, E. Leung, L. J. Yang, A. Matin and S. Ahmad, Beilstein J. Org. Chem., 2014, 10, 1919.

54 K. Saito and T. Wada, Tetrahedron Lett., 2014, 55, 1991.

55 A. T. Londregan, K. Burford, E. L. Conn and K. D. Hesp, Org. Lett., 2014, 16, 3336.

56 J. Bong, D. Shin and S. I. Kwon, Nucl. Instrum. Methods Phys. Res., Sect. A, 2014, 735, 314 .

57 C. H. Chen, J. Wu, B. T. Hsieh, D. S. Chen, T. H. Wang, S. H. Chien and Y. J. Chang, Radiat. Phys. Chem., 2014, 104, 192.

58 Y. R. Huang, Y. J. Chang, L. L. Hsieh, M. H. Liu, J. S. Liu, C. H. Chu and B. T. Hsieh, Radiat. Phys. Chem., 2014, 104, 414.

59 K. Pilarova, P. Kozubikova, J. Solc and V. Spevacek, Radiat. Phys. Chem., 2014, 104, 283.

60 C. H. Yao, W. T. Hsu, J. J. Lee, S. M. Hsu, P. Y. L. Ma, B. T. Hsieh and Y. J. Chang, J. Med. Biol. Eng., 2014, 34, 327.

61 S. Gil, C. Jimenez-Borja, J. Martin-Campo, A. Romero, J. L. Valverde and L. Sanchez-Silva, J. Colloid Interface Sci., 2014, 431, 105.

62 C. L. Liu, Y. K. Peng, S. W. Chou, W. H. Tseng, Y. J. Tseng, H. C. Chen, J. K. Hsiao and P. T. Chou, Small, 2014, 10, 3962.

63 S. Tabatabaei and S. K. Sadrnezhaad, Bull. Mater. Sci., 2014, 37, 1447.

64 B. Li, J. X. Li, L. X. Li, Y. P. Jiangi and Z. J. Li, J. Am. Leather Chem. Assoc., 2014, 109, 239.

65 X. S. Guo, J. M. Yang, Y. Liang, J. X. Liu and B. Y. Xiao, Bioprocess Biosyst. Eng., 2014, 37, 553.

66 D. Xu, Y. Li and T. Gu, Mater. Corros., 2014, 65, 837.

67 Z. W. Tan, C. Y. Wu, M. Zhang, W. Z. Lv, J. J. Qiu and C. M. Liu, RSC Adv., 2014, 4, 41705.

68 Z. W. Tan, M. Zhang, H. Z. Guo, J. J. Qiu and C. M. Liu, Des. Monomers Polym., 2014, 17, 762.

69 S. S. Denisov, E. A. Kotova, E. Y. Plotnikov, A. A. Tikhonov, D. B. Zorov, G. A. Korshunova and Y. N. Antonenko, Chem. Commun., 2014, 50, 15366. 
70 D. A. Stoyanovsky, J. F. Jiang, M. P. Murphy, M. Epperly, X. L. Zhang, S. Li, J. Greenberger, V. Kagan and H. Bayir, ACS Med. Chem. Lett., 2014, 5, 1304.

71 H. Braband, M. Benz and R. Alberto, Nucl. Med. Biol., 2014, 41, 613.

72 Y. M. Zheng, S. D. Ji, E. Tomaselli, C. Ernest, T. Freiji and S. Liu, Nucl. Med. Biol., 2014, 41, 813.

73 A. Haslop, L. Wells, A. Gee, C. Plisson and N. Long, Mol. Pharm., 2014, 11, 3818.

74 D. Y. Kim, H. S. Kim, H. Y. Jang, J. H. Kim, H. S. Bom and J. J. Min, ACS Med. Chem. Lett., 2014, 5, 1124.

75 S. L. Liu, D. Li, H. Shan, F. P. Gabbai, Z. B. Li and P. S. Conti, Nucl. Med. Biol., 2014, 41, 120.

76 J. Maddahi and R. R. S. Packard, Semin. Nucl. Med., 2014, 44, 333.

77 A. A. Neves and K. M. Brindle, J. Nucl. Med., 2014, 55, 1.

78 H. T. Ravert, D. P. Holt and R. F. Dannals, J. Labelled Cmpd. Radiopharm., 2014, 57, 695.

79 D. C. Yeo, C. Wiraja, A. Mantalaris and C. J. Xu, J. Biomed. Nanotechnol., 2014, 10, 2722.

80 G. F. Zhao, Y. M. Yu, T. M. Shoup, D. R. Elmaleh, A. A. Bonab, R. G. Tompkins and A. J. Fischman, J. Surg. Res., 2014, 188, 473.

81 Z. Q. Zhao, Q. Yu, T. T. Mou, C. Liu, W. J. Yang, W. Fang, C. Peng, J. Lu, Y. Liu and X. Z. Zhang, Mol. Pharm., 2014, 11, 3823.

82 O. O. Sogbein, M. Pelletier-Galarneau, T. H. Schindler, L. H. Wei, R. G. Wells and T. D. Ruddy, Biomed. Res. Int., 2014, 2014, 942960.

83 D. E. Morrison, J. B. Aitken, M. D. de Jonge, F. Issa, H. H. Harris and L. M. Rendina, Chem. - Eur. J., 2014, 20, 16602.

84 S. T. Chew, K. M. Lo, S. K. Lee, M. P. Heng, W. Y. Teoh, K. S. Sim and K. W. Tan, Eur. J. Med. Chem., 2014, 76, 397.

85 E. A. Dunn, M. Roxburgh, L. Larsen, R. A. J. Smith, A. D. McLellan, A. Heikal, M. P. Murphy and G. M. Cook, Biorg. Med. Chem., 2014, 22, 5320.

86 A. Y. Spivak, J. Keiser, M. Vargas, R. R. Gubaidullin, D. A. Nedopekina, E. R. Shakurova, R. R. Khalitova and V. N. Odinokov, Biorg. Med. Chem., 2014, 22, 6297.

87 C. Bland, E. M. Hartmann, J. A. Christie-Oleza, B. Fernandez and J. Armengaud, Mol. Cell. Proteomics, 2014, 13, 1369.

88 S. C. Turfus, J. M. Halket, M. C. Parkin, D. A. Cowan, R. A. Braithwaite and A. T. Kicman, Drug Test. Anal., 2014, 6, 500.

89 L. Chang, X. Z. Zhang, X. B. Shi, L. Zhao and X. M. Liu, J. Appl. Polym. Sci., 2014, 131, 40935.

90 L. Chang, X. Z. Zhang, X. B. Shi, L. Zhao and X. M. Liu, Fiber Polym., 2014, 15, 2026.

91 A. J. Guo, F. H. Wang, W. T. Lin, X. F. Xu, T. T. Tang, Y. Y. Shen and S. R. Guo, Int. J. Biol. Macromol., 2014, 67, 163.

92 T. Qiu, Q. Y. Zeng and N. J. Ao, Mater. Lett., 2014, 122, 13.

93 Y. Xue, Y. F. Pan, H. N. Xiao and Y. Zhao, RSC Adv., 2014, 4, 46887.

94 C. Li, Y. Liu, P. Cao, J. He, Z. S. Lin, N. J. Ao and B. Chu, Polym. Bull., 2014, 71, 2543.

95 X. Y. Zhang, X. P. Lü and P. F. Han, Desalin. Water Treat., 2014, 52, 6016.

96 F. L. Kong, J. Song, B. W. Cheng and Y. B. Zheng, Adv. Mater. Res., 2014, 842, 138.

97 N. D. Koromilas, G. C. Lainioti, C. Gialeli, D. Barbouri, K. B. Kouravelou, N. K. Karamanos, G. A. Voyiatzis and J. K. Kallitsis, PLos One, 2014, 9, e115183.

98 Y. H. Yang, Q. S. Shi, J. Feng, X. L. Shu and J. Feng, RSC Adv., 2014, 4, 50708. 
99 R. Simancas, J. L. Jorda, F. Rey, A. Corma, A. Cantin, I. Peral and C. Popescu, J. Am. Chem. Soc., 2014, 136, 3342.

100 S. K. Tiwari, A. Misra and D. V. Khakhar, Polym. Eng. Sci., 2014, 54, 2420.

101 H. Vashisht, I. Bahadur, S. Kumar, K. Bhrara, D. Ramjugernath and G. Singh, Int. J. Electrochem. Sci., 2014, 9, 2896.

102 H. Vashisht, I. Bahadur, S. Kumar, G. Singh, D. Ramjugernath and E. E. Ebenso, Int. J. Electrochem. Sci., 2014, 9, 5204.

103 H. Vashisht, S. Kumar, I. Bahadur and G. Singh, Int. J. Electrochem. Sci., 2014, 9, 684.

104 P. K. Leung, C. Ponce-de-Leon, F. J. Recio, P. Herrasti and F. C. Walsh, J. Appl. Electrochem., 2014, 44, 1025.

105 I. A. Aiad, S. M. Tawfik, S. M. Shaban, A. A. Abd-Elaal and M. El-Shafie, J. Surfactants Deterg., 2014, 17, 391.

106 C. Vogel and J. Meier-Haack, Desalination, 2014, 342, 156.

107 H. Touzi, Y. Chevalier, R. Kalfat and N. Jaffrezic-Renault, Eur. Polym. J., 2014, 56, 140.

108 K. Wang, X. C. Lin, G. P. Jiang, J. Z. Liu, L. Jiang, C. M. Doherty, A. J. Hill, T. W. Xu and H. T. Wang, J. Membr. Sci., 2014, 471, 27.

109 L. Xiong, S. Gu, K. O. Jensen and Y. S. S. Yan, ChemSusChem, 2014, 7, 114.

110 X. M. Yan, S. Gu, G. H. He, X. M. Wu, W. J. Zheng and X. H. Ruan, J. Membr. Sci., 2014, 466, 220.

111 P. Cotanda, G. Sudre, M. A. Modestino, X. C. Chen and N. P. Balsara, Macromolecules, 2014, 47, 7540.

112 M. S. Zhang, S. T. Hemp, M. Q. Zhang, M. H. Allen, R. N. Carmean, R. B. Moore and T. E. Long, Polym. Chem., 2014, 5, 3795.

113 A. Negrea, A. Popa, M. Ciopec, L. Lupa, P. Negrea, C. M. Davidescu, M. Motoc and V. Minzatu, Pure Appl. Chem., 2014, 86, 1729.

114 D. A. D'Amico, R. P. Ollier, V. A. Alvarez, W. F. Schroeder and V. P. Cyras, Appl. Clay Sci., 2014, 99, 254.

115 C. Prahsarn, N. Roungpaisan, N. Suwannamek, W. Klinsukhon, H. Hayashi, K. Kawasaki and T. Ebina, Clays Clay Miner., 2014, 62, 13.

116 K. Cinku and B. Baysal, Physicochem. Probl. Miner. Process., 2014, 50, 417.

117 H. F. Zhu, J. Li, Y. K. Zhu and S. J. Chen, Polym. Adv. Technol., 2014, 25, 872.

118 S. Suin, N. K. Shrivastava, S. Maiti and B. B. Khatua, Appl. Clay Sci., 2014, 95, 182.

119 S. Suin, S. Maiti, N. K. Shrivastava and B. B. Khatua, Mater. Des., 2014, 54, 553.

120 Y. Zhao, J. C. Wang, Y. C. Du, C. Pan and W. Zhao, Polym. Polym. Compos., 2014, 22, 799.

121 J. C. Wang, K. Sun, W. L. Hao, Y. C. Du and C. Pan, Appl. Clay Sci., 2014, 90, 109.

122 F. X. Geng, R. Z. Ma, Y. Yamauchi and T. Sasaki, Chem. Commun., 2014, 50, 9977.

123 T. Zeng, J. J. Pignatello, R. J. Li and W. A. Mitch, Environ. Sci. Technol., 2014, 48, 13392.

124 C. D. Magnusson and M. A. Kelland, Energy Fuels, 2014, 28, 6803.

125 U. Hyväkko, A. W. T. King and I. Kilpelainen, Bioresources, 2014, 9, 1565.

126 C. Jangu and T. E. Long, Polymer, 2014, 55, 3298.

127 K. R. Basvani, O. S. Fomina, D. G. Yakhvarov and J. Heinicke, Polyhedron, 2014, 67, 306.

128 S. I. Lall-Ramnarine, J. A. Mukhlall, J. F. Wishart, R. R. Engel, A. R. Romeo, M. Gohdo, S. Ramati, M. Berman and S. N. Suarez, Beilstein J. Org. Chem., 2014, 10, 271. 
129 W. I. S. Galpothdeniya, S. Das, S. L. De Rooy, B. P. Regmi, S. Hamdan and I. M. Warner, RSC Adv., 2014, 4, 17533.

130 M. Quiroz-Guzman, D. P. Fagnant, X. Y. Chen, C. J. Shi, J. F. Brennecke, G. S. Goff and W. Runde, RSC Adv., 2014, 4, 14840.

131 J. Estager, J. D. Holbrey and M. Swadzba-Kwasny, Chem. Soc. Rev., 2014, 43, 847.

132 A. Winter, K. Thiel, A. Zabel, T. Klamroth, A. Poppl, A. Kelling, U. Schilde, A. Taubert and P. Strauch, New J. Chem., 2014, 38, 1019.

133 E. Santos, J. Albo, A. Rosatella, C. A. M. Afonso and A. Irabien, J. Chem. Technol. Biotechnol., 2014, 89, 866.

134 P. Kübler and J. Sundermeyer, Dalton Trans., 2014, 43, 3750.

135 Y. Y. Li, X. F. Wu, Q. Y. Wu, H. Ding and W. F. Yan, Dalton Trans., 2014, 43, 13591.

136 J. Klomfar, M. Souckova and J. Patek, J. Chem. Eng. Data, 2014, 59, 2263.

137 M. S. AlTuwaim, K. H. A. E. Alkhaldi, A. S. Al-Jimaz and A. A. Mohammad, J. Chem. Eng. Data, 2014, 59, 1955.

138 D. Rabari, N. Patel, M. Joshipura and T. Banerjee, J. Chem. Eng. Data, 2014, 59, 571.

139 M. M. Alavianmehr, S. M. Hosseini and S. Amighi, J. Mol. Liq., 2014, 191, 166.

140 R. Q. Lu, J. Lin, Y. K. Lu and D. Liu, Chem. Phys. Lett., 2014, 597, 114.

141 Y. L. Wang, F. U. Shah, S. Glavatskih, O. N. Antzutkin and A. Laaksonen, J. Phys. Chem. B, 2014, 118, 8711.

142 M. M. Alavianmehr, S. M. Hosseini and J. Moghadasi, J. Mol. Liq., 2014, 197, 287.

143 M. Muramatsu, S. Morishima, T. Katayama, S. Ito, Y. Nagasawa and H. Miyasaka, J. Solution Chem., 2014, 43, 1550.

144 R. P. Morco, A. Y. Musa and J. C. Wren, Solid State Ionics, 2014, 258, 74.

145 R. Yonekura and M. W. Grinstaff, Phys. Chem. Chem. Phys., 2014, 16, 20608.

146 R. K. Blundell and P. Licence, Phys. Chem. Chem. Phys., 2014, 16, 15278.

147 P. J. Carvalho, S. P. M. Ventura, M. L. S. Batista, B. Schroder, F. Goncalves, J. Esperanca, F. Mutelet and J. A. P. Coutinho, J. Chem. Phys., 2014, 140, 064505.

148 I. J. Villar-Garcia, S. Fearn, G. F. De Gregorio, N. L. Ismail, F. J. V. Gschwend, A. J. S. McIntosh and K. R. J. Lovelock, Chem. Sci., 2014, 5, 4404.

149 S. B. Dhiman, G. S. Goff, W. Runde and J. A. LaVerne, J. Nucl. Mater., 2014, 453, 182 .

150 A. G. Santos, B. D. Ribeiro, D. S. Alviano and M. A. Z. Coelho, RSC Adv., 2014, 4, 37157.

151 K. Romanenko, L. Y. Jin, L. A. Madsen, J. M. Pringle, L. A. O'Dell and M. Forsyth, J. Am. Chem. Soc., 2014, 136, 15638.

152 J. A. Novoa-Lopez, E. L. Lago, M. Dominguez-Perez, J. Troncoso, L. M. Varela, R. de la Fuente, O. Cabeza, H. Michinel and J. R. Rodriguez, Opt. Laser Technol., 2014, 61, 1.

153 X. Y. Liu, W. Afzal and J. M. Prausnitz, J. Chem. Thermodyn., 2014, 70, 122.

154 N. Awwad, X. Y. Liu, W. Afzal and J. M. Prausnitz, Z. Phys. Chem., 2014, 228, 839.

155 M. Blahusiak and S. Schlosser, J. Chem. Thermodyn., 2014, 72, 54.

156 K. M. Barra, R. P. Sabatini, Z. P. McAtee and M. P. Heitz, J. Phys. Chem. B, 2014, 118, 12979.

157 A. Makowska, A. Hryniewicka and J. Szydlowski, Fluid Phase Equilib., 2014, $372,21$. 
158 A. Makowska, P. Papis and J. Szydlowski, Fluid Phase Equilib., 2014, $382,100$.

159 S. Omar, J. Lemus, E. Ruiz, V. R. Ferro, J. Ortega and J. Palomar, J. Phys. Chem. B, 2014, 118, 2442.

160 G. J. Maximo, R. J. B. N. Santos, P. Brandao, J. M. S. S. Esperanca, M. C. Costa, A. J. A. Meirelles, M. G. Freire and J. A. P. Coutinho, Cryst. Growth Des., 2014, 14, 4270.

161 F. S. G. Bagh, M. K. O. Hadj-Kali, F. S. Mjalli, M. A. Hashim and I. M. AlNashef, J. Mol. Liq., 2014, 199, 344.

162 W. Afzal, X. Y. Liu and J. M. Prausnitz, J. Chem. Eng. Data, 2014, 59, 954.

163 Y. H. Cui, Y. F. Chen, D. S. Deng, N. Ai and Y. Zhao, J. Mol. Liq., 2014, 199, 7.

164 J. M. Zhu, F. Xin, J. H. Huang, X. C. Dong and H. M. Liu, Chem. Eng. J., 2014, 246, 79.

165 J. M. Zhu, F. Xin, Y. C. Sun and X. C. Dong, Theor. Found. Chem. Eng., 2014, 48, 787.

166 E. Ali, M. K. Hadj-Kali, S. Mulyono, I. Alnashef, A. Fakeeha, F. Mjalli and A. Hayyan, Chem. Eng. Res. Des., 2014, 92, 1898.

167 S. Seo, M. Quiroz-Guzman, M. A. DeSilva, T. B. Lee, Y. Huang, B. F. Goodrich, W. F. Schneider and J. F. Brennecke, J. Phys. Chem. B, 2014, 118, 5740 .

168 S. Saravanamurugan, A. J. Kunov-Kruse, R. Fehrmann and A. Riisager, ChemSusChem, 2014, 7, 897.

169 S. Kasahara, E. Kamio and H. Matsuyama, J. Membr. Sci., 2014, 454, 155.

170 X. Y. Liu, E. Ruiz, W. Afzal, V. Ferro, J. Palomar and J. M. Prausnitz, Ind. Eng. Chem. Res., 2014, 53, 363.

171 X. Y. Liu, W. Afzal, M. G. He and J. M. Prausnitz, AlChE J., 2014, 60, 2607.

172 Q. He, J. W. O’Brien, K. A. Kitselman, L. E. Tompkins, G. C. T. Curtis and F. M. Kerton, Catal. Sci. Technol., 2014, 4, 1513.

173 M. Galvan, M. Selva, A. Perosa and M. Noe, Asian J. Org. Chem., 2014, 3, 504.

174 T. R. Gohndrone, T. B. Lee, M. A. DeSilva, M. Quiroz-Guzman, W. F. Schneider and J. F. Brennecke, ChemSusChem, 2014, 7, 1970.

175 T. Werner and H. Büttner, ChemSusChem, 2014, 7, 3268.

176 D. Wei-Li, J. Bi, L. Sheng-Lian, L. Xu-Biao, T. Xin-Man and A. Chak-Tong, Appl. Catal., A, 2014, 470, 183.

177 D. Wei-Li, J. Bi, L. Sheng-Lian, L. Xu-Biao, T. Xin-Man and A. Chak-Tong, Catal. Today, 2014, 233, 92.

178 J. X. Chen, B. Jin, W. L. Dai, S. L. Deng, L. R. Cao, Z. J. Cao, S. L. Luo, X. B. Luo, X. M. Tu and C. T. Au, Appl. Catal., A, 2014, 484, 26.

179 S. Livi, A. A. Silva, J. Pereira, T. K. L. Nguyen, B. G. Soares, M. B. Cardoso, J. F. Gerard and J. Duchet-Rumeau, Chem. Eng. J., 2014, 241, 103.

180 G. Fiorani and M. Selva, RSC Adv., 2014, 4, 1929.

181 M. Selva, A. Caretto, M. Noe and A. Perosa, Org. Biomol. Chem., 2014, 12, 4143.

182 A. A. Vasil'ev and S. G. Zlotin, Mendeleev Commun., 2014, 24, 23.

183 A. J. Keith, S. D. Kosik, L. M. V. Tillekeratne and M. R. Mason, Synlett, 2014, 25, 977.

184 L. W. Lee and H. M. Yang, Ind. Eng. Chem. Res., 2014, 53, 12257.

185 H. M. Yang, Y. H. Hung and C. Y. Tu, J. Taiwan Inst. Chem. Eng., 2014, 45, 1421.

186 A. Voros, Z. Baan, G. Timari, I. Hermecz, P. Mizsey and Z. Finta, Curr. Org. Synth., 2014, 11, 751.

187 A. Voros, Z. Mucsi, Z. Baan, G. Timari, I. Hermecz, P. Mizsey and Z. Finta, Org. Biomol. Chem., 2014, 12, 8036. 
188 Q. Wang, Z. M. Wu, Y. F. Li, Y. Tan, N. Liu and Y. J. Liu, RSC Adv., 2014, 4, 33466.

189 C. Y. Yang and T. J. Fang, Bioresour. Technol., 2014, 164, 198.

190 D. Rabari and T. Banerjee, Ind. Eng. Chem. Res., 2014, 53, 18935.

191 T. E. Sintra, R. Cruz, S. P. M. Ventura and J. A. P. Coutinho, J. Chem. Thermodyn., 2014, 77, 206.

192 J. M. Padró, R. B. P. Vidal and M. Reta, Anal. Bioanal. Chem., 2014, 406, 8021.

193 M. Kica, T. Vincent, A. Trochimczuk, R. Navarro and E. Guibal, Solvent Extr. Ion Exch., 2014, 32, 5431.

194 S. Lago, B. Rodriguez-Cabo, A. Arce and A. Soto, J. Chem. Thermodyn., 2014, $75,63$.

195 J. M. M. V. Sousa, J. F. O. Granjo, A. J. Queimada, A. G. M. Ferreira, N. M. C. Oliveira and I. M. A. Fonseca, J. Chem. Thermodyn., 2014, 79, 184.

196 H. F. Hizaddin, A. Ramalingam, M. A. Hashim and M. K. O. Hadj-Kali, J. Chem. Eng. Data, 2014, 59, 3470.

197 U. Domanska and M. Wlazlo, Fuel, 2014, 134, 114.

198 S. A. Dharaskar, K. L. Wasewar, M. N. Varma, D. Z. Shende, K. K. Tadi and C. K. Yoo, Fuel Process. Technol., 2014, 123, 1.

199 F. A. Vicente, L. P. Malpiedi, F. A. E. Silva, A. Pessoa, J. A. P. Coutinho and S. P. M. Ventura, Sep. Purif. Technol., 2014, 135, 259.

200 A. M. Ferreira, J. A. P. Coutinho, A. M. Fernandes and M. G. Freire, Sep. Purif. Technol., 2014, 128, 58.

201 S. Wellens, T. Vander Hoogerstraete, C. Moller, B. Thijs, J. Luyten and K. Binnemans, Hydrometallurgy, 2014, 144, 27.

202 A. Rout and K. Binnemans, Dalton Trans., 2014, 43, 1862.

203 A. Rout, E. R. Souza and K. Binnemans, RSC Adv., 2014, 4, 11899.

204 A. Rout, S. Wellens and K. Binnemans, RSC Adv., 2014, 4, 5753.

205 T. Vander Hoogerstraete and K. Binnemans, Green Chem., 2014, 16, 1594.

206 K. Larsson and K. Binnemans, Green Chem., 2014, 16, 4595.

207 T. Vander Hoogerstraete, B. Blanpain, T. Van Gerven and K. Binnemans, RSC Adv., 2014, 4, 64099.

208 M. Matsumiya, Y. Kikuchi, T. Yamada and S. Kawakami, Sep. Purif. Technol., 2014, 130, 91.

209 A. C. Barsanti, C. Chiappe, T. Ghilardi and C. S. Pomelli, RSC Adv., 2014, 4, 38848.

210 J. Castillo, M. T. Coll, A. Fortuny, P. N. Donoso, R. Sepulveda and A. M. Sastre, Hydrometallurgy, 2014, 141, 89.

211 R. Navarro, J. Alba, I. Saucedo and E. Guibal, J. Appl. Polym. Sci., 2014, 131, 41086.

212 R. Navarro, P. Ruiz, I. Saucedo and E. Guibal, Sep. Purif. Technol., 2014, 135, 268.

213 A. Negrea, L. Lupa, M. Ciopec and P. Negrea, Environ. Eng. Manage. J., 2014, 13, 2005.

214 A. Popa, M. Ciopec, A. Negrea, L. Lupa, P. Negrea, C. M. Davidescu, G. Ilia and N. Duteanu, Pure Appl. Chem., 2014, 86, 1741.

215 E. M. Martinis, P. Berton and R. G. Wuilloud, TrAc, Trends Anal. Chem., 2014, 60, 54.

216 M. Y. Yang, P. J. Zhang, L. Hu, R. H. Lu, W. F. Zhou, S. B. Zhang and H. X. Gao, J. Chromatogr. A, 2014, 1360, 47.

217 K. Tsunashima, Y. Sakai and M. Matsumiya, Electrochem. Commun., 2014, 39,30 .

218 S. Y. Bae, W. K. Shin and D. W. Kim, Electrochim. Acta, 2014, 125, 497. 
219 M. A. Baldo, P. Oliveri, R. Simonetti and S. Daniele, J. Electroanal. Chem., 2014, 731, 43.

220 P. P. Huang, P. C. Howlett and M. Forsyth, Corros. Sci., 2014, 80, 120.

221 C. Pozo-Gonzalo, C. Virgilio, Y. J. Yan, P. C. Howlett, N. Byrne, D. R. MacFarlane and M. Forsyth, Electrochem. Commun., 2014, 38, 24.

222 C. Pozo-Gonzalo, P. C. Howlett, J. L. Hodgson, L. A. Madsen, D. R. MacFarlane and M. Forsyth, Phys. Chem. Chem. Phys., 2014, 16, 25062.

223 L. H. J. Xiong, E. O. Barnes and R. G. Compton, Sens. Actuators, B, 2014, 200, 157.

224 N. Terasawa and K. Asaka, Sens. Actuators, B, 2014, 193, 851.

225 J. A. Marins, B. G. Soares, A. A. Silva and S. Livi, RSC Adv., 2014, 4, 50925.

226 A. S. Ionkin, B. M. Fish, Z. R. Li, L. Liang, M. E. Lewittes, L. K. Cheng, C. Westphal, J. G. Pepin and F. Gao, Sol. Energy Mater. Sol. Cells, 2014, 124, 39.

227 Y. J. Yan, T. Khoo, C. Pozo-Gonzalo, A. F. Hollenkamp, P. C. Howlett, D. R. MacFarlane and M. Forsyth, J. Electrochem. Soc., 2014, 161, A974.

228 L. Y. Jin, P. C. Howlett, J. M. Pringle, J. Janikowski, M. Armand, D. R. MacFarlane and M. Forsyth, Energy Environ. Sci., 2014, 7, 3352.

229 J. P. Tafur and A. J. F. Romero, J. Membr. Sci., 2014, 469, 499.

230 Y. Zhou, J. Dyck, T. W. Graham, H. M. Luo, D. N. Leonard and J. Qu, Langmuir, 2014, 30, 13301.

231 Z. B. Cai, H. M. Meyer, C. Ma, M. F. Chi, H. M. Luo and J. Qu, Wear, 2014, 319, 172.

232 B. Khemchandani, A. Somers, R. Howlett, A. K. Jaiswal, E. Sayanna and M. Forsyth, Tribol. Int., 2014, 77, 171.

233 I. Otero, E. R. Lopez, M. Reichelt, M. Villanueva, J. Salgado and J. Fernandez, ACS Appl. Mater. Interfaces, 2014, 6, 13115.

234 I. Otero, E. R. Lopez, M. Reichelt and J. Fernandez, Tribol. Int., 2014, 70, 104.

235 V. Totolin, I. Minami, C. Gabler, J. Brenner and N. Dorr, Tribol. Lett., 2014, 53, 421.

236 C. Gabler, N. Doerr and G. Allmaier, Tribol. Int., 2014, 80, 90.

237 E. E. Zvereva, S. Grimme, S. A. Katsyuba, V. V. Ermolaev, D. A. Arkhipova, N. Yan, V. A. Miluykov, O. G. Sinyashin and A. Aleksandrov, Phys. Chem. Chem. Phys., 2014, 16, 20672.

238 K. L. Ding, H. Lu, Y. C. Zhang, M. L. Snedaker, D. Y. Liu, J. A. Macia-Agullo and G. D. Stucky, J. Am. Chem. Soc., 2014, 136, 15465.

239 Z. Q. Tan, J. F. Liu, Y. G. Yin, Q. T. Shi, C. Y. Jing and G. B. Jiang, ACS Appl. Mater. Interfaces, 2014, 6, 19833.

240 J. González-Álvarez, J. J. Mangas-Alonso, P. Arias-Abrodo and M. D. Gutierrez-Alvarez, Anal. Bioanal. Chem., 2014, 406, 3149.

241 L. W. Hantao, A. Najafi, C. Zhang, P. Augusto and J. L. Anderson, Anal. Chem., 2014, 86, 3717.

242 F. P. Burns, P. A. Themens and K. Ghandi, Compos. Interfaces, 2014, 21, 59.

243 S. Y. Choi, H. Rodriguez, H. Q. N. Gunaratne, A. V. Puga, D. Gilpin, S. McGrath, J. S. Vyle, M. M. Tunney, R. D. Rogers and T. McNally, RSC Adv., 2014, 4, 8567.

244 S. Livi, V. Bugatti, B. G. Soares and J. Duchet-Rumeau, Green Chem., 2014, 16, 3758.

245 S. Livi, G. Sar, V. Bugatti, E. Espuche and J. Duchet-Rumeau, RSC Adv., 2014, 4, 26452. 
246 S. Livi, A. A. Silva, Y. Thimont, T. K. L. Nguyen, B. G. Soares, J. F. Gerard and J. Duchet-Rumeau, RSC Adv., 2014, 4, 28099.

247 T. K. L. Nguyen, S. Livi, S. Pruvost, B. G. Soares and J. Duchet-Rumeau, J. Polym. Sci., Part A: Polym. Chem., 2014, 52, 3463.

248 H. Maka, T. Spychaj and R. Pilawka, eXPRESS Polym. Lett., 2014, 8, 723.

249 B. G. Soares, A. A. Silva, S. Livi, J. Duchet-Rumeau and J. F. Gerard, J. Appl. Polym. Sci., 2014, 131, 39834.

250 S. Marceneiro, Q. Y. Hu, A. M. A. Dias, I. Lobo, I. Dias, E. de Pinho, M. G. Rasteiro and H. C. de Sousa, Ind. Eng. Chem. Res., 2014, 53, 16061.

251 R. C. Zhang, S. M. Hong and C. M. Koo, J. Appl. Polym. Sci., 2014, 131, 40648.

252 C. Y. Xing, X. Zheng, L. Q. Xu, J. J. Jia, J. Ren and Y. J. Li, Ind. Eng. Chem. Res., 2014, 53, 4304.

253 D. Glas, J. Hulsbosch, P. Dubois, K. Binnemans and D. E. De Vos, ChemSusChem, 2014, 7, 610.

254 M. Czugala, C. O’Connell, C. Blin, P. Fischer, K. J. Fraser, F. Benito-Lopez and D. Diamond, Sens. Actuators, B, 2014, 194, 105.

255 S. Gallagher, L. Florea, K. J. Fraser and D. Diamond, Int. J. Mol. Sci., 2014, 15, 5337.

256 Y. Deguchi, Y. Kohno and H. Ohno, Aust. J. Chem., 2014, 67, 1666.

257 A. Fortuny, M. T. Coll and A. M. Sastre, Desalination, 2014, 343, 54.

258 W. I. S. Galpothdeniy, K. S. McCarter, S. L. De Rooy, B. P. Regmi, S. Das, F. Hasan, A. Tagge and I. M. Warner, RSC Adv., 2014, 4, 7225.

259 W. Q. Zhang, S. G. Jiang, C. Hardacre, P. Goodrich, K. Wang, Z. Y. Wu and H. Shao, Energy Fuels, 2014, 28, 4333.

260 Y. F. Zhang, M. Forsyth and B. R. W. Hinton, ACS Appl. Mater. Interfaces, 2014, 6, 18989.

261 A. R. Schultz, P. M. Lambert, N. A. Chartrain, D. M. Ruohoniemi, Z. Y. Zhang, C. Jangu, M. Zhang, C. B. Williams and T. E. Long, Acs Macro Lett., 2014, 3, 1205.

262 M. Ahmadi, R. Amiri and S. Mohammadi, Bull. Chem. Soc. Ethiop., 2014, 28, 137.

263 A. Dorehgiraee, E. T. Kermani and H. Khabazzadeh, J. Chem. Sci., 2014, 126, 1039.

264 I. F. Zeid, M. M. Said, S. A. Darwish and F. M. Soliman, Monatsh. Chem., 2014, 145, 639.

265 M. A. Abd-El-Maksoud, S. S. Maigali and F. M. Soliman, J. Heterocycl. Chem., 2014, 51, 1830.

266 Y. Han, Y. J. Sheng and C. G. Yan, Org. Lett., 2014, 16, 2654.

267 Y. W. Lin, J. C. Deng, Y. Z. Hsieh and S. C. Chuang, Org. Biomol. Chem., 2014, 12, 162.

268 W. Petz and B. Neumüller, Eur. J. Inorg. Chem., 2014, 2014, 1218.

269 S. A. Solomon, L. K. Allen, S. B. J. Dane and D. S. Wright, Eur. J. Inorg. Chem., 2014, 2014, 1615.

270 S. M. Habibi-Khorassani, M. T. Maghsoodlou, A. Ebrahimi, E. Aghdaei and M. A. Kazemian, Res. Chem. Intermed., 2014, 40, 2729.

271 G. T. Huang, T. Lankau and C. H. Yu, Org. Biomol. Chem., 2014, 12, 7297.

272 J. N. Ji, D. C. Meng, X. Y. Zhang, L. P. Meng and Y. L. Zeng, J. Mol. Model., 2014, 20, 2282.

273 A. B. Rozhenko, S. S. Mykhaylychenko, N. V. Pikun, Y. G. Shermolovich and J. Leszczynski, Int. J. Quantum Chem., 2014, 114, 241. 
274 Y. Al Jasem, R. El-Esawi and T. Thiemann, J. Chem. Res., 2014, 453.

275 Z. Chen, Y. Nieves-Quinones, J. R. Waas and D. A. Singleton, J. Am. Chem. Soc., 2014, 136, 13122.

276 E. E. Coyle, B. J. Doonan, A. J. Holohan, K. A. Walsh, F. Lavigne, E. H. Krenske and C. J. O'Brien, Angew. Chem., Int. Ed., 2014, 53, 12907.

277 W. H. Huang, S. H. Zhao and G. P. Dong, Phosphorus, Sulfur, Silicon Relat. Elem., 2014, 189, 1802.

278 P. Wang, S. H. Liao, J. B. Zhu and Y. Tang, Chem. Commun., 2014, 50, 808.

279 Y. L. Tsai, S. E. Syu, S. M. Yang, U. Das, Y. S. Fan, C. J. Lee and W. W. Lin, Tetrahedron, 2014, 70, 5038.

280 T. Werner, M. Hoffmann and S. Deshmukh, Eur. J. Org. Chem., 2014, 6873.

281 T. Tsuji, K. Suzuki, T. Nakamura and T. Nishi, Tetrahedron, 2014, 70, 5234.

282 T. Yamauchi, J. Takidaira, K. Okamoto, T. Sugiura, H. Horikoshi, S. Kudo, S. Sasaki, N. Mizushima and K. Higashiyama, Heterocycles, 2014, 88, 1175.

283 M. Ostermeier and R. Schobert, J. Org. Chem., 2014, 79, 4038.

284 H. I. C. Lowe, N. J. Toyang, C. T. Watson and J. Bryant, Nat. Prod. Commun., 2014, 9, 687.

285 M. S. Andra and C. C. Tzschucke, Eur. J. Org. Chem., 2014, 7265.

286 K. J. Hale and L. P. Wang, Org. Lett., 2014, 16, 2154.

287 T. Ivan, L. Vacareanu and M. Grigoras, Des. Monomers Polym., 2014, 17, 156.

288 B. J. Laughlin, M. K. Burdette, C. R. Powell, B. E. Levy, A. G. Tennyson and R. C. Smith, Eur. J. Org. Chem., 2014, 5998.

289 F. Wang, L. C. Li, C. F. Ni and J. B. Hu, Beilstein J. Org. Chem., 2014, 10, 344.

290 Q. Li, J. H. Lin, Z. Y. Deng, J. Zheng, J. Cai and J. C. Xiao, J. Fluorine Chem., 2014, 163, 38.

291 V. V. Levin, A. L. Trifonov, A. A. Zemtsov, M. I. Struchkova, D. E. Arkhipov and A. D. Dilman, Org. Lett., 2014, 16, 6256.

292 W. Lu, J. Gao, J. K. Yang, L. Liu, Y. L. Zhao and H. C. Wu, Chem. Sci., 2014, 5, 1934.

293 R. A. Aitken, G. Barker, L. P. Cleghorn, E. J. Reid and S. S. Roberts, Heterocycles, 2014, 88, 1135.

294 R. Zhou, C. Duan, C. J. Yang and Z. J. He, Chem. - Asian J., 2014, 9, 1183.

295 G. T. Huang, T. Lankau and C. H. Yu, J. Org. Chem., 2014, 79, 1700.

296 S. J. Sabounchei, M. Ahmadi, T. Azizi and M. Panahimehr, Synlett, 2014, 25, 336.

297 S. J. Sabounchei, M. Ahmadi, M. Panahimehr, F. A. Bagherjeri and Z. Nasri, J. Mol. Catal. A: Chem., 2014, 383, 249.

298 S. J. Sabounchei, M. Panahimehr, M. Ahmadi, F. Akhlaghi and C. Boscovic, C. R. Chim., 2014, 17, 81.

299 S. J. Sabounchei, M. Panahimehr, M. Hosseinzadeh, R. Karamian, M. Asadbegy and A. Masumi, J. Mol. Struct., 2014, 1061, 90.

300 S. J. Sabounchei, M. Panahimehr, H. R. Khavasi, F. A. Bagherjeri and C. Boscovic, Chem. Pap., 2014, 68, 624.

301 S. J. Sabounchei, M. Pourshahbaz, A. Hashemi, M. Ahmadi, R. Karamian, M. Asadbegy and H. R. Khavasi, J. Organomet. Chem., 2014, 761, 111.

302 W. T. Gong, D. Na, H. Mehdi, J. W. Ye and G. L. Ning, J. Organomet. Chem., 2014, 772, 314.

303 P. Kubler, B. Oelkers and J. Sundermeyer, J. Organomet. Chem., 2014, 767, 165. 
304 C. Martschitsch and U. Schubert, Monatsh. Chem., 2014, 145, 577.

305 K. Searles, B. Pinter, C. H. Chen and D. J. Mindiola, Organometallics, 2014, 33, 4192.

306 A. K. Swarnakar, S. M. McDonald, K. C. Deutsch, P. Choi, M. J. Ferguson, R. McDonald and E. Rivard, Inorg. Chem., 2014, 53, 8662.

307 S. Samiee and Z. Mahdavifar, Polyhedron, 2014, 72, 72.

308 X. Ye, L. Yang, Z. Wu, G. Ren, Y. Lu, T. Sun, Q. Lei, W. Fang and H. Xie, New J. Chem., 2014, 38, 4115. 